\title{
DISTRIBUTION OF CRAYFISH IN EUROPE AND SOME ADJOINING COUNTRIES.
}

\author{
D.M. HOLDICH \\ School of Life and Environmental Sciences, University of Nottingham, \\ NOTTINGHAM NG7 2RD, England.
}

\begin{abstract}
The distribution of crayfish in Europe is examined using information from a variety of sources mainly for the last two decades. All European countries have at least one indigenous crayfish species (ICS), many with large stocks, and most countries in Western Europe have at least one non-indigenous crayfish species (NICS). Some species termed indigenous in certain countries may have been introduced in relatively recent times. However, the meaning of the term indigenous (native) varies between countries. NICS continue to expand their ranges and present a continued threat to ICS through competition and transmission of diseases, notably crayfish plague. The current high level of interest in crayfish means that many countries are monitoring their crayfish situation and, where necessary, taking steps to renew stocks of threatened indigenous species, some of which are apparently on the verge of extinction. A more regular monitoring programme for European crayfish as a whole is needed if the demise of indigenous species is to be prevented.
\end{abstract}

Key-words : crayfish, indigenous, non-indigenous, taxonomy, distribution, Europe.

\section{DISTRIBUTION GÉOGRAPHIQUE DES ÉCREVISSES EN EUROPE ET DANS CERTAINS PAYS ADJACENTS.}

\section{RÉSUMÉ}

La distribution géographique des écrevisses européennes est examinée à l'aide de données recueillies en majorité au cours des deux dernières décennies et provenant de diverses sources. Tous les états européens ont au moins une espèce d'écrevisse indigène (en anglais, indigenous crayfish species - ICS), souvent avec des stocks importants. De plus, la plupart des états en Europe de l'ouest ont au moins une espèce d'écrevisse nonindigène (en anglais, non-indigenous crayfish species - NICS). Dans certains pays, des espèces reconnues comme étant indigènes peuvent en fait avoir été introduites 
récemment. La signification des termes « indigène » et « natif » est variable entre les pays. La distribution des NICS continue à s'étendre et menace sans cesse les ICS à travers la compétition et la transmission de maladies, notamment la peste. Le regain de l'intérêt porté aux écrevisses dans plusieurs pays européens engendre une meilleure gestion des stocks qui se traduit par une surveillance accrue des populations et le renouvellement des populations menacées des espèces indigènes, qui sont parfois en voie de disparition. Un programme de surveillance pour toutes les écrevisses européennes sera nécessaire pour prévenir la disparition des espèces indigènes.

Mots-clés : écrevisses, indigène, non-indigène, taxonomie, distribution, Europe.

\section{INTRODUCTION}

Over the last two decades there has been a plethora of papers on the distribution of European crayfish, although no recent attempt has been made to look at their current pan-European distribution. As shown below such an overview is now more difficult since the advent of genetic techniques, the uncertain status of some taxa - particularly in Eastern Europe, and changes in political boundaries. What is presented below is not meant to be a definitive picture of crayfish distribution in Europe, but an attempt to collate some of the more recent information. It is not based on original observations but on what other astacologists have written or told me personally. Consequently, much of the information has had to be taken at face value. The author hopes that readers will correct and add to Table II by contacting him. LOWERY and HOLDICH (1988) show very generalized maps of the distribution of crayfish in Europe. Those produced for this paper are more accurate but still rather generalized - the production of an atlas showing crayfish distribution at a more precise level, e.g. on a 10 kilometre square basis, would be more meaningful, but such data is not yet available for every European country.

The reason for the current interest in crayfish mainly has to do with protecting native or indigenous crayfish species (ICS) from the threats of alien or non-indigenous crayfish species (NICS), as well as those caused by human activity, e.g. habitat alteration, pollution, etc. Despite the problems being caused by NICS in Europe and elsewhere they are obviously not considered of high priority by the leaders of the Global Invasive Species Programme, as they receive scant mention in their recent strategy document (McNEELY et al., 2001). However, many governments have introduced legislation to try and protect their ICS and to try and stop the spread of NICS originating from North America and their associated disease, aphanomycosis (crayfish plague) (see papers in GHERARDI and HOLDICH, 1999). Crayfish plague has had a profound impact on the distribution of ICS in Europe. The history of its spread is dealt with in detail by ALDERMAN (1996), who shows that virtually every country in Europe had been affected by 1995. In addition, both ICS and NICS are covered by European legislation, e.g. Berne Convention and Habitats Directive (TAYLOR, 2001). However, in recent years some governments have changed their legislation to allow the import and movement of live NICS. This could have further implications for their ICS, and also for those in neighbouring countries. In order to manage the situation regular monitoring of the distribution of both ICS and NICS is needed. Although many countries have detailed maps for the distribution of crayfish for certain time periods very few have regular monitoring programmes.

The main aims of this paper are to: 1) to comment on the taxonomy of European crayfish; 2) comment on the dispersal of crayfish in Europe since the last ice age; 3) list those factors that have affected the modern distribution of European crayfish; 4) tabulate and map the distribution of crayfish in Europe by country (plus adjoining countries having crayfish) based on data (literature) mainly from the last two decades; 5) collate and discuss 
the recent literature for each European country having crayfish (plus adjoining countries); 6) speculate as to the future of European crayfish, stressing the importance of regular monitoring.

In this review the eastern boundary of Europe will be taken as the Ural Mountains, the Ural River, the north-west part of the Caspian Sea, and the Caucasus Mountains, and thus includes the western parts of Russia and Kazakhstan. Bordering countries such as Georgia, Armenia, Azerbaijan, Iran, Turkey and Turkmenistan all have crayfish but geographically these countries are in Asia. Crayfish do not naturally occur in Africa (TAYLOR, 2001), but those North African countries, i.e. Morocco and Egypt, having populations of introduced species will also be mentioned.

\section{TAXONOMY}

The situation concerning the taxonomy of crayfish in Europe has been in a state of flux for many decades, and still is, particularly for those species in the Ponto-Caspian Basin. There have been five taxonomic revisions of European crayfish in the last half century with diversity ranging from five species, assigned to one genus (e.g. ALBRECHT, 1982) to 19, assigned to five genera (e.g. STAROBOGATOV, 1995; see Table I). The latter view, proliferated by UDEKEM D'ACOZ (1999), has yet to meet with universal approval, mainly because many species, subspecies, varieties and nations (infrasubspecies) have been created, elevated or resurrected with little new evidence for doing so other than to make the names more available from a nomenclatorial point of view. STAROBOGATOV (1995) has largely based his views on those of BOTT $(1950)$, KARAMAN $(1962,1963)$ and BRODSKY (1983). ALBRECHT (1982) dismissed BOTT's (1950) system, deciding instead on one genus, Astacus, with only five European species, i.e. A. astacus, leptodactylus, pachypus, pallipes and torrentium. ALBRECHT (1983) did, however, recognize three subspecies of Astacus, i.e. astacus, balanicus and colchicus. Subsequently, workers have accepted the view that $A$. pallipes and $A$. torrentium should be in a separate genus, Austropotamobius, but not in two genera, i.e. Austropotamobius torrentium and Atlantoastacus pallipes as suggested by BOTT (see HOLDICH, 1992). STAROBOGATOV's (1995) revision of the indigenous crayfish species in Europe is given in Table I. However, such schemes are not accepted by all workers in Eastern Europe, which has resulted in different names for the same crayfish being used within the same journal. As pointed out by SOKOLSKY and MIKOUIZA (2000) much more work is needed before such a revision is accepted. If modern molecular genetic techniques are applied to crayfish from Eastern Europe it will be interesting to see if the situation becomes clearer or even more complicated!

The main problem concerns $A$. leptodactylus, a very « plastic » species from the morphological, ecological, and physiological points of view. BRODSKY (1983) provides a lot of evidence for placing the Ponto-Caspian crayfish in the genus Pontastacus in agreement with BOTT (1950) rather than in Astacus. However, this has yet to be taken up by astacologists in Western Europe, who prefer (as the author of this paper has done), rightly or wrongly, to refer just to $A$. leptodactylus, and presume that any subspecies is also leptodactylus - but are they? KÖKSAL (1988) recognised four species: A. leptodactylus leptodactylus Eschscholtz, A. I. salinus Nordmann, A. I. eichwaldii Bott, and A. I. cubanicus Birnstein and Winogradow, and these, along with $A$. I. boreoorientalis (Birnstein and Vinogradov) (see Table I), do appear to be recognizable from each other by astacologists in Kazakhstan, Russia, Turkmenistan and the Ukraine (see comments below). Whether they warrant a taxonomic ranking higher than the subspecies level needs further investigation. Similar arguments apply to Astacus pachypus, which is recognized by some East European astacologists as a separate genus, Caspiastacus Starobogatov, with two species (see Table I). 


\section{Table I}

STAROBOGATOV's (1995) revision of indigenous European crayfish (letters and numbers have been added).

\section{Tableau I}

La révision des espèces indigènes d'écrevisses européennes par STAROBAGATOV (1995) (les lettres et les nombres ont été ajoutés).

A. Astacus Fabricius, 1775

1. Astacus astacus (Linnaeus, 1758)

1a. A. a. astacus (Linnaeus, 1758)

1b. A. a. chanadzhiae (Starobogatov, 1995)

(for Astacus a. a. natio canadżia M. Karaman, 1963, and A. a. a. natio ptetzmanni M. Karaman, 1963)

2. Astacus balanicus (S. Karaman, 1929)

2a. A. b. balanicus (S. Karaman, 1929)

2b. A. b. graecus (Starobogatov, 1995)

(for A. a. b. natio graeca M. Karaman, 1963)

3. Astacus colchicus (Kessler, 1876)

B. Atlantoastacus Bott, 1950

4. Atlantoastacus pallipes (Lereboullet, 1858)

4a. A. p. pallipes (Lereboullet, 1858)

4b. A. p. rhodanicus (Starobogatov, 1995)

(for A. p. var. rhodanicus Laurent \& Suscillon, 1962)

5. Atlantoastacus fulcisianus (Ninni, 1886)

5a. A. f. fulcisianus (Ninni, 1886)

(inc. Austropotamobius berndhauseri Bott, 1972, Astacus pallipes var. lombardicus Albrecht, 1982, A. pallipes var. trentinicus Albrecht, 1982)

5b. A. f. italicus (Faxon, 1914)

6. Atlantoastacus orientalis (S. Karaman, 1929)

6a. A. o. orientalis (S. Karaman, 1929)

(including Austropotamobius pallipes carsicus M. Karaman, 1962, and Astacus pallipes var. dalmatinicus Albrecht, 1982)

6b. A. o. carinthiacus Starobogatov, 1995

(after Astacus pallipes var. carinthiacus Albrecht, 1981)

7. Atlantoastacus lusitanicus (Mateus, 1934)

C. Austropotamobius Skorikov, 1908

8. Austropotamobius torrentium (Shrank, 1803)

8a. A. t. torrentium (Shrank, 1803)

8b. A. t. danubicus (Starobogatov, 1995)

(for A. $t$. natio danubicus M. Karaman, 1963)

8c. A. t. macedonicus (S. Karaman, 1929)

(inc. Potamobius torrentium dalmatinus S. Karaman, 1929)

D. Pontastacus Bott, 1950

9. Pontastacus angulosus (Rathke, 1837)

10. Pontastacus cubanicus (Birstein and Vinogradov, 1934)

11. Pontastacus danubialsis (Brodsky, 1981)

12. Pontastacus eichwaldi (Bott, 1950)

12a. P. e. eichwaldi (Bott, 1950)

12b. P. e. bessarabicus Brodsky, 1981

13. Pontastacus intermedius Brodsky, 1981

14. Pontastacus kessleri (Schimkewitsch, 1884)

15. Pontastacus leptodactylus (Eschscholtz, 1823)

15a. P. I. boreoorientalis (Birnstein and Vinogradov, 1934)

15b. P. I. leptodactylus Eschscholtz, 1823

16. Pontastacus pylzowi (Skorikow, 1911)

17. Pontastacus salinus (Nordmann, 1842)

E. Caspiastacus Starobogatov, 1995

18. Caspiastacus daucinus (Brodsky, 1981)

19. Caspiastacus pachypus (Rathke, 1837)

Note: natio is the term given to an infrasubspecific category 
Various genetic techniques are being used to gradually unravel the complexities of the taxonomy of west European crayfish, however, the situation still remains fluid as different techniques can yield conflicting results, e.g. BOTT's (1972) Austropotamobius « berndhauseri » (see below). So far genetic analysis has mainly been confined to $A$. pallipes. a species with a range that stretches from the west of the Republic of Ireland, south to Spain, and across to the Dalmatian coast (HOLDICH, 1996). On a morphological basis, three sub-species of $A$. pallipes, i.e. pallipes, lusitanicus and italicus were recognized by BOTT (1950), whilst KARAMAN $(1962,1963)$ recognized two species, $A$. pallipes and $A$. italicus, but subdivided italicus into three subspecies, italicus, lusitanicus and carsicus. LAURENT and SUSCILLON (1962) added a variety, A. p. p. rhodanicus from France (see Table I, 4b), and ALBRECHT $(1981,1982)$ added other varieties (see Table I, $5 \mathrm{a}, 6 \mathrm{a}, 6 \mathrm{~b})$, including $A$. p. carinthiacus, from Austria. SANTUCCl et al. (1997) using electrophoretic techniques detected three population groups corresponding to A. torrentium, A. pallipes and $A$. italicus from various parts of Europe, but did not confirm A. Iusitanicus as being a separate species. SOUTY-GROSSET et al. $(1997,1999)$ and GRANDJEAN et al. (2001a), however, using molecular markers, confirmed the subspecific status of $A$. p. pallipes, $A$. $p$. italicus and $A$. p. lusitanicus. Using morphological, electrophoretic and molecular techniques, LÖRTSCHER et al. (1997) and LARGIADÈR et al. (2000) confirmed BOTT's (1972) Austropotamobius berndhauseri for southern Switzerland.

Based on mDNA studies GRANDJEAN et al. (2000) have recently proposed a new classification for Austropotamobius based on four species: A. torrentium, A. berndhauseri, A. pallipes and $A$. italicus, with the latter containing three subspecies, italicus, carinthiacus and carsicus. However, the specific status of $A$. berndhauseri is now doubtful and GRANDJEAN et al. (2002) consider it to be A. italicus carsicus, however, they reconfirm $A$. pallipes and $A$. italicus as valid species, with the latter having three subspecies - italicus, carinthiacus, and carsicus. MACHINO (1997b), however, is of the opinion, based on morphological characters, that carinthiacus is not valid, but is part of the $A$. $p$. italicus complex. What can be said is that the $A$. pallipes taxon appears to represent a highly structured species complex. Added to this are the views of STAROBOGATOV (1995), where Austropotamobius is placed in the genus Atlantoastacus with four species and seven subspecies (Table I).

To simplify matters for this paper only five ICS and four NICS will be dealt with. Austropotamobius pallipes and Astacus leptodactylus are probably best considered as species complexes:

Astacus astacus (Linnaeus) - the noble crayfish

Astacus leptodactylus (Eschscholtz) species complex - the narrow-clawed crayfish

Astacus pachypus (Rathke) - the thick-clawed crayfish

Austropotamobius pallipes (Lereboullet) species complex - the white-clawed crayfish

Austropotamobius torrentium (Shrank) - the stone crayfish

Orconectes limosus (Rafinesque) - the North American spiny-cheek crayfish

Pacifastacus leniusculus (Dana) - the North American signal crayfish

Procambarus clarkii (Girard) - the North American red swamp crayfish

Cherax destructor (Clark) - the Australian yabby 


\section{POST-GLACIAL DISPERSAL OF CRAYFISH IN EUROPE}

The dispersal of indigenous crayfish throughout Europe after the last ice age is an extremely complicated story. ALBRECHT (1983) examined the views of previous workers in detail, e.g. BIRNSTEIN and WINOGRADOW $(1934)$, BOTT $(1950,1972)$ and KARAMAN (1962, 1963), and applied new findings in biogeography, palaeogeography and historical geology to try and work out the original Holocene spreading of freshwater crayfish in Europe. He came to the conclusion that the post-Pleistocene distribution of crayfish has been heavily influenced by humans through introductions and the construction of canals. He states that the oldest records for introductions date back to the $15^{\text {th }} \mathrm{C}$ and that it was common practice to trade in them as a food and for medicinal purposes. One of the earliest mentions of crayfish was by ARISTOTLE in $300 \mathrm{BC}$, and although they were being eaten as early as 1200 , it was not until the Middle Ages that their popularity increased and huge quantities were consumed (SKURDAL and TAUGBØL, 2001). ALBRECHT (1983) doubted the natural occurrence of crayfish in Finland, Norway and Sweden. He also considered that crayfish were originally absent from the Iberian Peninsula, the British Isles, North Germany and Switzerland immediately after the last ice age, and that the original distribution of crayfish in Europe was connected to the history of the Tertiary inland sea, the Paratethys, which became partitioned into basins of brackish and freshwater during the Neogene.

ALBRECHT (1983) presumed that during the last ice age any crayfish populations in northern Europe would either have been eliminated or pushed further and further south. Even further south he considers that conditions would probably have been inhospitable for most crayfish species with large areas of tundra and its associated permafrost. $\mathrm{He}$ suggests that the northern borderline of crayfish during the last ice age coincided with the southern borderline of the permafrost. In Figure $7 \mathrm{a}$, he shows $A$. pallipes restricted to south-eastern France, northern Italy and the Dalmatian coast; $A$. torrentium and $A$. astacus restricted to the Balkans and northern Greece; and A. leptodactylus and A. pachypus restricted to the Black and Caspian Seas - all behind the border of the permafrost. Subsequently, according to him, $A$. astacus and $A$. torrentium mainly migrated into Europe using the Danube drainage system. From the Black and Caspian Seas A. leptodactylus pushed forward to the north. He only mentions $A$. pallipes in the context of how it might have reached the British Isles (see below). However, according to some workers it may be that certain crayfish populations survived in refugia and were the centres of spreading when the ice melted, as has been suggested for other animal groups (HEWITT, 1996). There is some genetic evidence for this viewpoint (e.g. SANTUCCl et al., 1997; SOUTY-GROSSET et al., 1997; GRANDJEAN and SOUTY-GROSSET, 2000; GRANDJEAN et al., 2001b).

There is also speculation as to how some of the current marginal populations subsequently came about. For example are the populations of $A$. pallipes in Britain natural or introduced by man in relatively recent times? There is a lack of genetic diversity in A. pallipes from Britain suggesting a recent origin (GRANDJEAN et al., 1997a). There is also a strong genetic similarity to some populations in northern France, suggesting that British A. pallipes may have originated from there (GRANDJEAN et al., 1997b). Whether this was by tribes moving north with the melting ice when the British Isles were connected to mainland Europe some 6000 years ago, or much more recently, i.e. in the last 1000 years, is not known. One also has to consider the fact that as the ice melted some of the rivers between mainland Europe and the British Isles were joined, so colonisation of the British Isles by $A$. pallipes may also have been natural, as has occurred with some fish species (GEORGE, 1962; ALBRECHT, 1983; MAITLAND and CAMPBELL, 1992). GRANDJEAN and SOUTY-GROSSET (2000) also found no genetic differences amongst the most northern French and the British populations, whereas there was marked interpopulation genetic diversity in southern French populations. They thought that the former observation may be due to the fact that new areas free from the retreating ice were generally colonized by a limited number of individuals and consequently only represent a 
small part of the genetic pool present in refugial zones. The latter observation is probably due to habitat fragmentation and subsequent recolonizations from refugial areas during the Pleistocene. SOUTY-GROSSET et al. (2000) state that records for Ireland date back 300 years, but as with Britain genetic studies have shown a remarkable homogeneity across the country and have revealed similarities with stocks in north-west France. It is possible that crayfish have been introduced relatively recently either by French monastic orders or from Britain.

SOUTY-GROSSET et al. (1997) have suggested that at least three refugia were formed during the last ice age: the first in the Iberian Peninsula, the second the Balkans, and the third in the south of France; north-western Europe being colonized from this latter refuge after the last ice period. GRANDJEAN et al. (2001a) have elaborated further on this matter and, based on RFLP analysis from mDNA, have suggested at least four main refugia for $A$. pallipes during the Pleistocene, which could have been located in the Balkans, Carpathians, Italy and France. Three clusters with specific haplotypes have been found in north-western France and Britain, southern France and northern Italy. Each had low genetic differentiation, thus indicating recent divergence during the last periods of glaciation with three refugia located in the Atlantic French region, Mediterranean French region and Italy. England and northern France could have been colonized by individuals from Atlantic refugia. They also suggest that translocation by humans may explain the origin of Irish and Spanish crayfish stocks. SANTUCCI et al. (1997) suggest that the high genetic variability they found amongst $A$. pallipes italicus ( $A$. italicus according to them) populations from Italy can be explained by multiple refugial areas during the Quaternary cold periods in Italy.

\section{FACTORS AFFECTING THE MODERN DISTRIBUTION}

The modern distribution of ICS in Europe is a result of a complex set of general and crayfish related factors:

General:

- habitat modification, both natural and man-made, including droughts and floods

- canal building

- pollution, mainly since the Industrial Revolution in the $\mathrm{C} 18$, including acidification

- impact of stocking predatory fish, e.g. eels.

Crayfish related:

- natural migrations of ICS after the last ice age some 10000 years ago

- isolation of populations in refugia by glacial activity followed by spreading from such centres as the ice melted

- introduction and subsequent spread of crayfish plague from the 1860s, and its reintroduction with North American crayfish from the 1960s onwards

- translocations of Astacus leptodactylus from Eastern Europe

- translocations of ICS within and between countries for trade, stocking and farming

- introduction and subsequent establishment of NICS from North America, i.e. Oroconectes limosus (1890), Pacifastacus leniusculus (1960s) and Procambarus clarkii (1970s); and Australia, i.e. Cherax destructor (1980s). 


\section{WHAT IS MEANT BY « INDIGENOUS »?}

As a result of the above factors all countries in Europe have at least one ICS, and the majority in Western Europe also have one or more NICS, only Ireland and Norway being free of them at present (Table II). However, different countries tend to have different views as to what is meant by the term " indigenous » or " native ". If the species is considered as desirable in the freshwater environment then it is often considered native, even if its introduction is relatively recent, e.g. some species in Austria. This view may even prevail with NICS. Finland and Sweden, for example, probably consider $P$. leniusculus as a desirable addition to their freshwater fauna (ACKEFORS, 1999) and perhaps one day may list it as an indigenous species. One the other hand, where there is no recent tradition for eating crayfish as in Britain, the addition of $P$. leniusculus to the freshwater fauna is considered by many to be a bad thing (HOLDICH, 1999a) and, no matter how widespread it becomes, it is likely to remain labelled as a non-indigenous species.

\section{Table II}

Occurrence of wild populations of crayfish in Europe and some adjoining countries. This tables updates (and corrects where necessary) HOLDICH et al. (1999c) and SKURDAL and TAUGBøL (2001).

\section{Tableau II}

Distribution des populations sauvages d'écrevisses en Europe et dans certains pays adjacents. Cette table met à jour et corrige si nécessaire les travaux de HOLDICH et al. (1999c) et SKURDAL et TAUGBØL (2001).

Aa, Astacus astacus; Al, Astacus leptodactylus; Ap, Astacus pachypus; Aup, Austropotamobius pallipes; Aut, Austropotamobius torrentium; Cd, Cherax destructor, $\mathrm{OI}$, Orconectes limosus; Oi, Orconectes immunis; PI, Pacifastacus leniusculus; Pc, Procambarus clarkii.

* Crayfish indigenous to Europe as a whole, but not necessarily indigenous to a country where they now occur, having being introduced in recent times. However, in many cases, they are now considered indigenous by that country.

* Écrevisses indigènes du continent européen; certaines ne sont pas nécessairement indigènes à chaque pays où elles sont présentes actuellement parce qu'elles ont été introduites. Ces dernières peuvent néanmoins, dans plusieurs cas, être considérées comme indigènes par ce pays.

? Present in adjoining countries and may be recorded with more intensive surveying.

? Présentes dans les pays adjacents et pourraient être trouvées grâce à des recherches plus approfondies.

?? Indicates that an introduction has been made but its outcome is not known or is yet to be reported officially.

?? Indique qu'on a fait une introduction dont le résultat est inconnu ou non-officiel.

$\mathrm{R}$ Restricted distribution, i.e. one or few populations, but may be locally abundant, e.g. $A$. pallipes and $P$. leniusculus in Scotland.

$R$ Distribution géographique réduite, c'est-à-dire quelques populations, mais qui peuvent néanmoins être abondante, par exemple A. pallipes et $\mathrm{P}$. leniusculus en Ecosse. 
Indigenous to Europe*

Non-indigenous to Europe

\begin{tabular}{|c|c|c|c|c|c|c|c|c|c|c|}
\hline & $\mathrm{Aa}$ & $\mathrm{Al}$ & $A p$ & Aup & Aut & $\mathrm{Cd}$ & $\mathrm{Ol}$ & Oi & $\mathrm{PI}$ & $\mathrm{Pc}$ \\
\hline Albania & $x$ & $?$ & & & $x$ & & & & & \\
\hline Andorra & $\mathrm{x}$ & & & & & & & & & \\
\hline Armenia & & $\mathrm{x}$ & & & & & & & & \\
\hline Austria & $x$ & $\mathrm{x}$ & & $x$ & $x$ & & $x$ & & $x$ & \\
\hline Azerbaijan & & & $x$ & & & & & & & \\
\hline Azores (Portugal) & & & & & & & & & & $\mathrm{x}$ \\
\hline Balearic Is (Spain) & & & & & & & & & & $x$ \\
\hline Belarus & $x$ & $\mathrm{x}$ & & & & & $\mathrm{x}$ & & & \\
\hline Belgium & $\mathrm{x}$ & $\mathrm{x}$ & & & & & $\mathrm{x}$ & & $\mathrm{x}$ & \\
\hline Bosnia-Herz. & $x$ & $\mathrm{x}$ & & $x$ & $x$ & & & & & \\
\hline Bulgaria & $\mathrm{x}$ & $\mathrm{x}$ & $?$ & & $\mathrm{x}$ & & & & & \\
\hline Canary Is (Spain) & & & & & & & & & & $x$ \\
\hline Corsica (France) & . & & & $x$ & & & & & & \\
\hline Croatia & $x$ & $\mathrm{x}$ & & $x$ & $x$ & & & & & \\
\hline Cyprus & $? ?$ & & & & & & & & $? ?$ & ?? \\
\hline Czech Rep. & $x$ & $\mathrm{x}$ & & & $x$ & & $x$ & & $x$ & \\
\hline Denmark & $\mathrm{x}$ & $\mathrm{x}$ & & & & & & & $x$ & \\
\hline Egypt & & & & & & & & & & $\mathrm{x}$ \\
\hline England & $x$ & $\mathrm{x}$ & & $x$ & & & $x$ & & $x$ & $x$ \\
\hline Estonia & $x$ & & & & & & & & & \\
\hline Finland & $x$ & $\mathrm{R}$ & & & & & & & $\mathrm{x}$ & \\
\hline France & $x$ & $\mathrm{x}$ & & $\mathrm{x}$ & $\mathrm{R}$ & & $\mathrm{x}$ & & $x$ & $x$ \\
\hline Georgia & $x$ & $\mathrm{x}$ & & & & & & & & \\
\hline Germany & $x$ & $\mathrm{x}$ & & $x$ & $x$ & & $\mathrm{x}$ & $x$ & $x$ & $x$ \\
\hline Greece & $x$ & $\mathrm{x}$ & & & $x$ & & & & $? ?$ & \\
\hline Hungary & $\mathrm{x}$ & $\mathrm{x}$ & & & $\mathrm{x}$ & & $\mathrm{x}$ & & & \\
\hline Iran & & $\mathrm{x}$ & & & & & & & & \\
\hline Ireland North. & & & & $x$ & & & & & & \\
\hline Ireland Rep. & & & & $x$ & & & & & & \\
\hline Italy & $\mathrm{R}$ & $\mathrm{x}$ & & $x$ & $\mathrm{R}$ & & $x$ & & $\mathrm{R}$ & $x$ \\
\hline Kaliningrad (Russia) & $\mathrm{x}$ & $\mathrm{x}$ & & & & & $\mathrm{x}$ & & $\mathrm{x}$ & \\
\hline Kazakhstan & & $\mathrm{x}$ & $x$ & & & & & & & \\
\hline Latvia & $x$ & $\mathrm{x}$ & & & & & & & $\mathrm{x}$ & \\
\hline Liechtenstein & $\mathrm{R}$ & & & $\mathrm{R}$ & & & & & & \\
\hline Lithuania & $\mathrm{x}$ & $\mathrm{x}$ & & & & & $x$ & & $\mathrm{x}$ & \\
\hline Luxembourg & $\mathrm{R}$ & & & & $\mathrm{R}$ & & $\mathrm{x}$ & & $\mathrm{x}$ & \\
\hline Macedonia & $x$ & $?$ & & & $x$ & & & & & \\
\hline Moldova & $x$ & $\mathrm{x}$ & & & & & & & & \\
\hline Morocco & $\mathrm{x}$ & & & & & & $\mathrm{x}$ & & & \\
\hline Netherlands & $\mathrm{x}$ & $\mathrm{x}$ & & & & & $\mathrm{x}$ & & $\mathrm{x}$ & $x$ \\
\hline Norway & $\mathrm{x}$ & & & & & & & & & \\
\hline Poland & $x$ & $\mathrm{x}$ & & & & & $\mathrm{x}$ & & $\mathrm{x}$ & \\
\hline Portugal & & & & $\mathrm{R}$ & & & & & $\mathrm{x}$ & $x$ \\
\hline Romania & $x$ & $\mathrm{x}$ & & & $x$ & & & & & \\
\hline Russia & $x$ & $\mathrm{x}$ & $x$ & & & & & & ?? & \\
\hline Scotland & & & & $\mathrm{R}$ & & & & & $\mathrm{R}$ & \\
\hline Slovakia & $x$ & $\mathrm{x}$ & & & $x$ & & & & & \\
\hline Slovenia & $x$ & & & $x$ & $x$ & & & & & \\
\hline Spain & & & & $x$ & & $x$ & & & $\mathrm{x}$ & $x$ \\
\hline Sweden & $\mathrm{x}$ & & & & & & & & $x$ & \\
\hline Switzerland & $\mathrm{x}$ & $\mathrm{x}$ & & $x$ & $\mathrm{x}$ & & $x$ & & $\mathrm{x}$ & $x$ \\
\hline Turkey & $? ?$ & $\mathrm{x}$ & & & & & & & & \\
\hline Turkmenistan & & $\mathrm{x}$ & $x$ & & & & & & & \\
\hline Ukraine & $x$ & $\mathrm{x}$ & $x$ & & & & & & & \\
\hline Uzbekistan & & $x$ & & & & & & & & \\
\hline Wales & & & & $x$ & & & & & $\mathrm{x}$ & \\
\hline Yugoslavia & $x$ & $\mathrm{x}$ & & & $x$ & & & & & \\
\hline
\end{tabular}


BULLOCK et al. (1997) define an indigenous or native species as « Any species or race whose dispersal into an area has occurred independently of human activity and could have occurred at any time, including the present », whilst McNEELY et al. (2001) define it as one « ... living within its natural range (past or present), including the area which it can reach and occupy using its own legs, wind/water-borne or other dispersal systems, even if seldom found there ».

However, purists, in Britain at least, consider that a species should have been present since prehistoric times, i.e. since at least the last glaciation, c. $14000 \mathrm{BP}$, or since the Neolithic, c. 6000 BP (WEBB, 1985; STUBBS, 1988). The difficulty is that without the presence of recent fossils it is very difficult to prove whether a species has been present for that long. Relatively recent crayfish fossils are known from Finland, Germany, and England (BELL, 1920), but ALBRECHT (1983) gives little credence to the validity of those from German and English deposits and suggested that they belonged to post-glacial immigrations. ALBRECHT (1983) mentioned the fact that there were a lot of freshwater fossil sediments in Europe containing a whole spectrum of freshwater fauna, but with very little evidence for fossil crayfish.

\section{MODERN DISTRIBUTION}

According to ALBRECHT (1983), the modern distribution of indigenous European crayfish is as follows:

- Astacus astacus: from northern Greece over the whole of the Balkans, all of midand western Europe, Scandinavia, and large parts of eastern Europe (Ukraine, White Russia, Poland, Lithuania, Lativia, Estonia) to the White Sea in the north.

- Astacus pallipes: British Isles, Iberian Peninsula, France, Switzerland, Italy, and the Dalmatian coast of Yugoslavia.

- Astacus torrentium: Balkans (Romania, Yugoslavia, northern Greece), Hungary, Austria and the German low mountain ranges up to the Moselle, and northern and eastern Switzerland.

- Astacus leptodactylus: Anatolian Plateau (Turkey), east Balkans, whole of eastern Europe and Russia up to the Urals, with an isolated population in Tashkent (Uzbekistan).

- Astacus pachypus: restricted to the Black and Caspian Seas.

The EIFAC report on the status of crayfish stocks in Europe produced by WESTMAN et al. (1990) was the first attempt to try and get information from all European countries, albeit by means of a questionnaire. Although it contains some errors some of the information has not been published elsewhere and is therefore of use to the current review. The results generally confirm ALBRECHT's (1983) view on the distribution of ICS. Respondents to the questionnaire reported that $A$. astacus was decreasing in many countries due to crayfish plague, pollution, man-made environmental change, and overfishing. Astacus leptodactylus was reported to be decreasing in Germany, Turkey and Bulgaria for the same reasons above, plus the impact of eels in Germany, but to be increasing in France and the Netherlands. Austropotamobius pallipes was reported to be decreasing in France, Italy, Spain, UK, for the same reasons above, plus poaching in Italy, although no change was reported in the former Yugoslavia. Little information was given on A. torrentium as it was not considered to be of much commercial importance. 
HENTONNEN and HUNER (1999) have provided a brief historical overview of the introduction of NICS into Europe. The first to be introduced was $O$. limosus with 100 specimens from the Delaware River (Pennsylvania, USA) into a small fishpond in Barnowko village in Germany that was connected to the Mysla River, a tributary of the Oder River. Successful introductions of this species were also made into the R. Cher in France between 1911-13. In Poland they were introduced in 1911 to Lake Sieroslawskie. Further introductions were made in the 1900s to Austria, France and Germany. It was not then until 1959 that Sweden, in a search for an alternative for $A$. astacus, introduced $P$. leniusculus from various rivers in the western USA. These were released into lakes and ponds in 1960. The introduction was successful and subsequently large numbers of specimens were introduced from Lake Tahoe. By 1969, 67 natural waters had been stocked. Pacifastacus leniusculus was introduced into south and central Finland from two Californian lakes from 1967-69, and in 1971-72 further specimens were introduced from Sweden. Pacifastacus leniusculus was introduced into Austria in 1970, Poland in 1971 and Germany 1972, and then into many other European countries (LEWIS, 2001). Procambarus clarkii was introduced into Spain in 1973, where it quickly became widely established and has subsequently been spread to other European countries. Various attempts have been made to introduce Cherax species from Australia into Europe for farming purposes, e.g. Italy (D'AGARO et al., 1999; GHERARDI et al., 1999) but, as far as is known, only one area in Spain has a wild population (see below).

There follows an account of the crayfish thought to be now present in the wild in each European country (and adjoining countries where present). A summary of the information is given in Table II and, with the exception of $A$. pachypus, which mainly occurs in coastal regions, and $C$. destructor and $O$. immunis, which have very limited distributions, the distribution of ICS and NICS is also shown as maps in Figures 1-7.

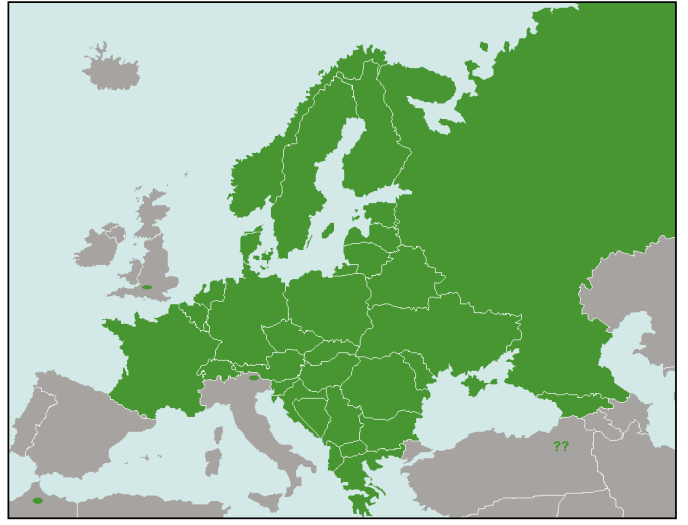

Figure 1: Astacus astacus.

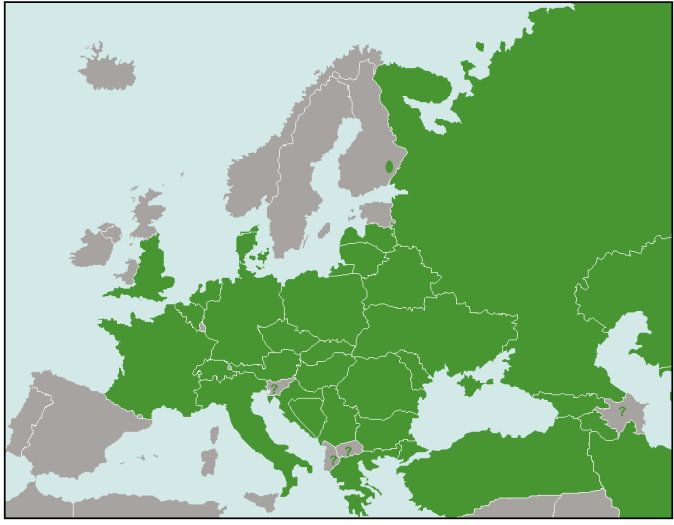

Figure 2: Astacus leptodactylus.

\section{Figures 1-2}

Generalized distribution of crayfish in Europe and some adjoining countries.

\section{Figures 1-2}

Distribution générale des écrevisses en Europe et dans certains pays adjacents. 


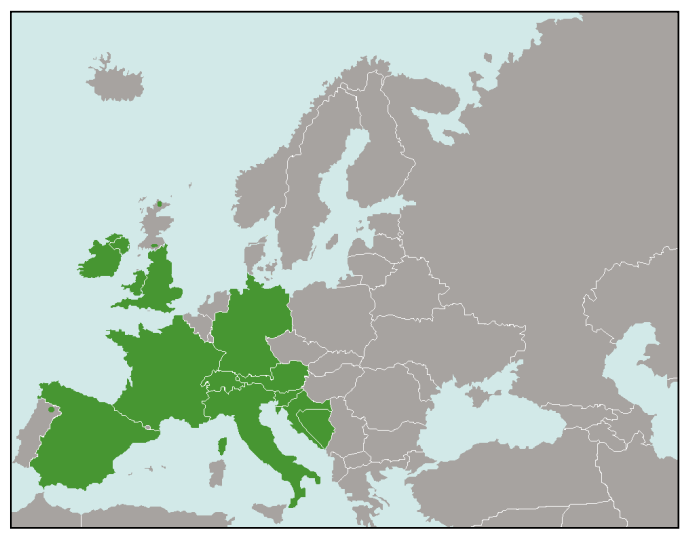

Figure 3: Austropotamobius pallipes.

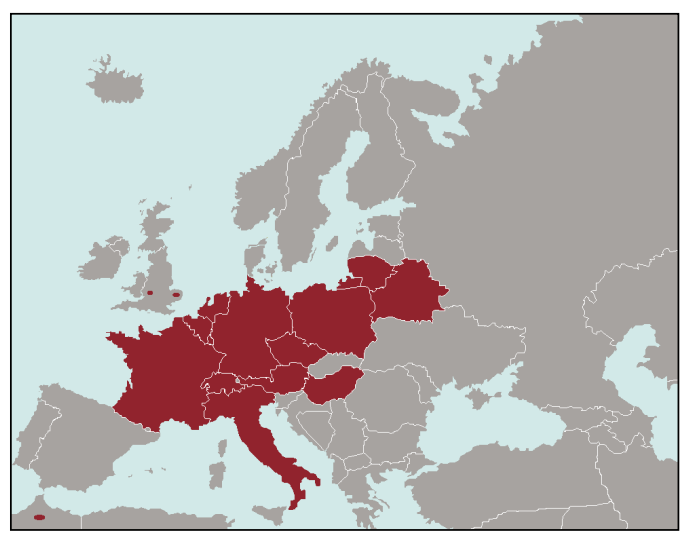

Figure 5: Orconectes limosus.

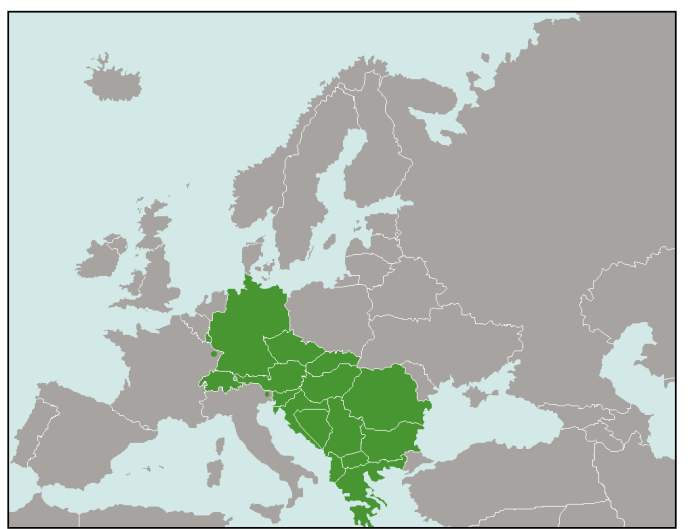

Figure 4: Austropotamobius torrentium.

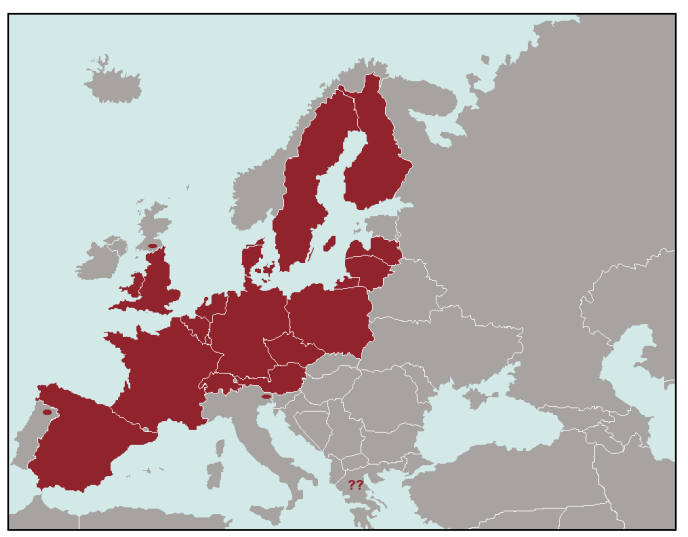

Figure 6: Pacifastacus leniusculus.

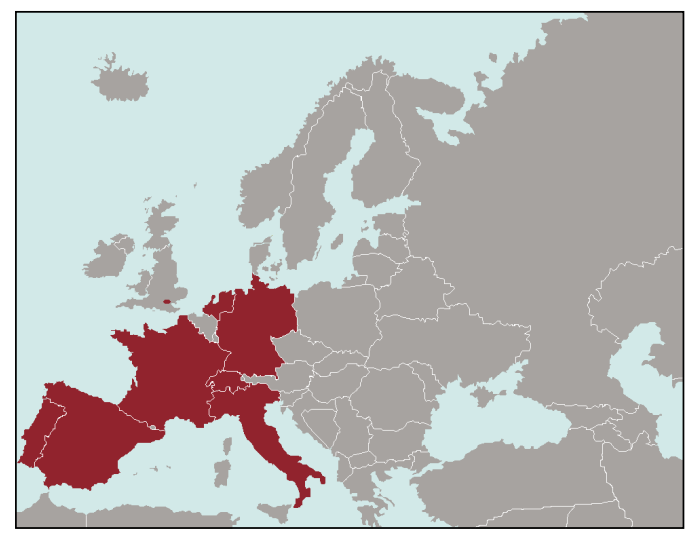

Figure 7: Procambarus clarkii.

Figures 3-7

Generalized distribution of crayfish in Europe and some adjoining countries.

Figures 3-7

Distribution générale des écrevisses en Europe et dans certains pays adjacents. 


\section{Albania}

SKURDAL and TAUGBØL (2001) list $A$. astacus as being indigenous, and A. torrentium is also present according to Y. MACHINO (pers. comm.), but no further information is available on either species at present.

\section{Andorra}

Two or three populations of $A$. astacus are known at between 800 and $1000 \mathrm{~m}$; there are no NICS (T. CHANGEUX, pers. comm., 2001)

\section{Armenia}

Little information is available for Armenia except that $A$. leptodactylus was introduced into Lake Seven in the early 1980s and is now found throughout this reservoir (GABRIELIAN and HOVHANNISIAN, 1999).

\section{Austria}

Astacus astacus, A. pallipes and A. torrentium are considered indigenous to Austria by some astacologists (WESTMAN et al., 1990; PÖCKL, 1999a, b), whilst A. leptodactylus, has been introduced. However, WESTMAN et al. (1990) reported $A$. leptodactylus as being indigenous to eastern parts of Austria. According to PÖCKL (1999a, b) Astacus astacus occurs throughout Austria but is restricted to lakes and larger streams with plenty of refuges. Austropotamobius torrentium is the most widely-spread crayfish, mainly in higher regions and wooded headwaters. Isolated populations of $A$. pallipes are only known from Gitschtal in the Carinthian Gail Basin (var. carinthiaca) and Tyrolean Plansee (var. trentinicus). As restocking with $A$. astacus was not apparently successful then A. leptodactylus was introduced from Eastern Europe in 1891 to replenish stocks decimated by crayfish plague from 1878 onwards. However, such stockings were not very successful and $A$. leptodactylus now has only a scattered distribution, but can be very locally abundant. Pacifastacus leniusculus was introduced from California in 1970, and later in 1970s from Sweden. It is now known from 119 localities. Orconectes limosus was imported in 1970 and is now found in 11 localities, including the Danube River system since 1985. Procambarus clarkii is not known from wild but is sold in fish markets. A number of papers in EDER and HÖDL (1998) also deal with the distribution of crayfish in Austria.

Although previously only known from the Gitschtal Valley in western Carinthia, MACHINO (1997b) recently found four new localities for $A$. pallipes close to the border with north-east Italy in the Gail Valley and Drave Valley in Carinthia. Austropotamobius torrentium was also found in the same area.

FÜREDER and MACHINO (1998) state that $A$. torrentium is uncommon in Austrian lakes, especially at high altitude. However, they recorded it at $1126 \mathrm{~m}$ a.s.l. in Haldensee, a Tyrolean lake. They also provide a useful table showing the maximum altitudes at which indigenous European crayfish occur, e.g. A. astacus (1 $516 \mathrm{~m}$, Austria), A. pallipes (1 $220 \mathrm{~m}$, Switzerland), and A. torrentium (1 $700 \mathrm{~m}$, Bulgaria). FÜREDER and MACHINO (1995) recorded $A$. pallipes at $976 \mathrm{~m}$ from the Plansee (Tyrol). A large population has developed in the lake, probably as a result of an introduction from northern ltaly at the start of the $20^{\text {th }} \mathrm{C}$.

ALBRECHT (1983) believed that all $A$. astacus in the Tyrol were the result of stockings. FÜREDER and MACHINO (1999) agree with this although they point out that it has been present in North Tyrol (Austria) since at least 1504. In East Tyrol $A$. astacus is the only species found so far and it was probably introduced between 1485 and 1504. They 
also think that $A$. pallipes was introduced in the first half of the $20^{\text {th }} \mathrm{C}$, and that only A. torrentium can be considered indigenous to Austria. These authors give a lot of historical information about the crayfish situation in Austria.

\section{Azerbaijan}

CHERKASHINA (1999a, b) gives details of the biology of $A$. pachypus (as Caspiastacus pachypus) in the Caspian Sea. Her distribution map shows that this species occurs in the coastal waters off Baku, the capital of Azerbaijan.

\section{Belarus}

According to KULESH et al. (1999) A. astacus mainly occurs in the Baltic Sea basin near the northern border with Russia. In only two cases has it been found in the Black Sea basin. It is found in 32 water bodies, mainly small rivers and numbers seem to be on the increase. Orconectes limosus is found near the Lithuanian and Polish borders in the west. ALEKHNOVICH et al. (1999a) report that O. limosus was first found in Grondo Province in west-central Belarus in 1997, although it is thought to have been in the region for 6-10 years and probably immigrated from Poland. It is now present in a number of rivers, including the Nemar River that drains into the Baltic Sea. Astacus leptodactylus is considered to be indigenous and is widely distributed in the Baltic and Black Sea basins. It is found in eutrophic lakes and reservoirs and, according to ALEKHNOVICH et al. (1999b), its numbers have dropped catastrophically since the 1960s.

\section{Belgium}

GERARD (1986) carried out a survey between 1982-85 and found three species occurring in the wild: the indigenous $A$. astacus and the non-indigenous, $O$. limosus and $A$. leptodactylus. The distribution of $A$. astacus was found to be limited to some sparse and isolated populations, mainly in the south. Relatively dense populations occurred in 18 out of 43 places examined in the survey. Four out of 18 involved running water, the others were private ponds. Orconectes limosus was found to be widely spread, its invasion from Germany and/or France probably having occurred at the end of the 1950s. Astacus leptodactylus was present in many private ponds but did not appear to occur in running water. Pacifastacus leniusculus had been introduced to six sites in 1979 for purposes of aquaculture. WESTMAN et al. (1990) state that it was introduced from the USA and Sweden in 1979. ARRIGNON et al. (1999a) updated the picture and reported $O$. limosus to be present in 30 out of 120 streams, and 103 out of 388 ponds having crayfish; P. leniusculus was present in 39 ponds out of 388 , and 27 out of 120 streams having crayfish in 1997; and $A$. leptodactylus was found in 109 ponds and 17 streams. Procambarus clarkii had not yet been reported from the wild. $O$. limosus and $P$. leniusculus had increased their ranges in the last 10 years whilst that of $A$. astacus had undergone a $67 \%$ reduction in the same period.

\section{Bosnia-Herzegovina}

According to BUDHINA (1989) A. italicus carsicus (= A. pallipes) and A. leptodactylus occur in Bosnia. In 2000 the author was sent a photograph of a crayfish from Bosnia (J. ARTHUR, pers. comm.) that he identified as A. torrentium. KARAMAN $(1962,1963)$ also lists $A$. astacus for this geographical area.

\section{British Isles (England, Republic of Ireland, Northern Ireland, Scotland, Wales)}

Austropotamobius pallipes is considered to be the only crayfish indigenous to the British Isles, however, as shown above, it may have been introduced relatively recently into Britain from France and then from Britain into Ireland. Although the range of $A$. pallipes has 
been reduced somewhat by the advent of crayfish plague in the 1980s (ALDERMAN, 1996) it still has a widespread distribution in England, Ireland and Wales (HOLDICH et al., 1995, 1999b; HOLDICH and ROGERS, 1997; REYNOLDS, 1997), and some populations are very dense. It occupies a wide range of lacustrine and riverine habitats, particularly in areas of easily-weathered rocks, where the calcium levels are relatively high. Austropotamobius pallipes is the sole crayfish species in Ireland and is widespread in rivers and lakes (REYNOLDS, 1997; REYNOLDS et al., 2002a, b). It has a high growth rate in lakes that probably hold some of the best stocks in Western Europe. Some of the largest lakes (> $2000 \mathrm{ha}$ ) contain stocks only near the mouths of inflowing rivers, possibly due to the impact of eels. Despite having no NICS a plague outbreak occurred in Lough Lene in 1987 and is suspected of causing mortalities elsewhere. Until recently only one introduced (in the 1940s) population of $A$. pallipes was known from Scotland, but recently another over 50 years old has been discovered (MAITLAND et al., 2001).

Five non-indigenous crayfish have been introduced into Britain (Table II), all of which have become established in the wild in England, but only one, P. leniusculus, in Scotland and Wales. Pacifastacus leniusculus and $A$. leptodactylus are now very widespread in England, overlapping with the range of $A$. pallipes (HOLDICH and REEVE, 1991; HOLDICH et al., 1995, 1999b; HOLDICH and ROGERS, 1997). Pacifastacus leniusculus was introduced for aquacultural purposes in the 1970s and has since escaped or been introduced into hundreds of wild sites. More is now harvested from the wild than from culture (ROGERS and HOLDICH, 1995; HOLDICH, 1999b). It was introduced into a number of farming sites in Scotland (HOLDICH et al., 1995) but, until recently, none were known from the wild. In 1995 one population was found in the south west of the country (R. Dee), and in 1999 they were found in the R. Clyde (MAITLAND, 1996; MAITLAND et al., 2001). A number of populations also exist in Wales (HOLDICH et al., 1995). There is concern about the amount of damage $P$. leniusculus is doing to the freshwater environment and legislation has been introduced to try and stop its spread and its associated disease, crayfish plague (HOLDICH et al., 1999b). Astacus leptodactylus was originally introduced into fish markets in England in the 1970s and has since escaped or been deliberately introduced into the wild. Some very large lacustrine populations now exist in the south and these are being harvested (ROGERS and HOLDICH, 1995). Although $P$. clarkii has been known from one site in England for a number of years the population has only been proved to be breeding recently (RICHTER and WILES, 2000). A single wild population of $A$. astacus exists in south-western England having escaped from a fish farm in the 1980s (HOLDICH et al., 1995, 1999b; HOLDICH and ROGERS, 1997). There have been three reports of the presence of $O$. limosus in ponds in England and it is thought that they are breeding (W.D. ROGERS, pers. comm.; P.J. SIBLEY, pers. comm.), but no studies have been made on them to date.

NICS have not become established in Northern Ireland or the Republic of Ireland due to legislation that prevents their import (HOLDICH and ROGERS, 1997; REYNOLDS, 1997; HOLDICH et al., 1999b).

\section{Bulgaria}

CUKERZIS (1988) states that $A$. astacus is found in the north, in the R. Danube basin. According to SKURDAL and TAUGBØL (2001) both $A$. astacus and $A$. leptodactylus are indigenous. A. ZAIKOV (pers. comm., 1998) confirmed this and added $A$. torrentium to the list. A. leptodactylus is apparently the most widespread crayfish species in rivers, lakes, and artificial lakes. Austropotamobius torrentium occurs with certainty in the south-western mountains region (G. GROZEV, pers. comm., 2002). BULGURKOV (1964) and SKURDAL and TAUGBØL (2001) list $A$. pachypus as indigenous to Bulgaria, but according to A. ZAIKOV and G. GROZEV (pers. comm., 2002), it is not known to them and there has been no other report than that of BULGURKOV. No NICS have been reported from Bulgaria. 


\section{Croatia}

BUDHINA (1989) reports that $A$. astacus, $A$. leptodactylus and A. torrentium danubica are present. SANTUCCl et al. (1997) used $A$. pallipes (as $A$. italicus) from Croatia in their genetic studies, and GOTTSTEIN et al. (1999) studied the biology of A. pallipes italicus in limnocrenic springs in the Nereta delta region. They state that the species has been eliminated from the main river by intensive draining and pollution. I. MAGUIRE (pers. comm., 2002) has confirmed the presence of $A$. pallipes in coastal regions, as well as the presence of $A$. astacus, $A$. leptodactylus and $A$. torrentium in some water courses, including some mixed populations of $A$. astacus and $A$. torrentium.

\section{Cyprus}

According to WESTMAN et al. (1990) three species have been introduced: A. astacus from Denmark in 1976 and 1978; P. leniusculus from Sweden in 1979 and 1980, and $P$. clarkii from Singapore in 1983. However, it is not known what has happened to these introductions since.

\section{Czech Republic}

ĎURIŠ (1989) reports that there are numerous populations of $A$. astacus in rivers and reservoirs in the Ostravice River drainage area, the largest tributary of the R. Oder. $\mathrm{He}$ also states (pers. comm., 1989) that $A$. astacus and $A$. torrentium are considered indigenous, whilst $A$. leptodactylus although considered indigenous was in fact introduced from eastern Poland in the late 1800s. Orconectes limosus entered the northern border of Czechia from Germany about 15-20 years ago and is now widely spread. Pacifastacus leniusculus was also been introduced to a few localities in the 1970s. KOZÁK et al. (2002) and POLICAR and KOZÁK (2001) have updated this by stating that $A$. astacus is most abundant in brooks, small rivers and ponds; $A$. torrentium, which reaches the limit of its north-east distribution in the Czech Republic, may only occur in four localities; $A$. leptodactylus occurs in quarry pits in southern and eastern Bohemia; P. leniusculus occurs in a few ponds and lakes; and $O$. limosus is expanding in the Elbe and Vltava rivers and in some of their tributaries. GROOMBRIDGE (1993) says A. pallipes is also present but according to Y. MACHINO (pers. comm.) this is in error.

\section{Denmark}

SKURDAL et al. (1999) mention that no mapping of ICS and NICS is carried out in Denmark. However, it is known that $A$. astacus is widely spread on the Jutland Peninsula and the islands of Funen and Zealand, although stocks have been reduced since the early 1900 s as a result of eutrophication and changes to habitat. It is not apparently clear if stocks were originally affected by crayfish plague although mortalities were recorded in 1907. Astacus leptodactylus and P. leniusculus were introduced in the 1970s, and $P$. leniusculus is now widespread on farms and in the wild. They have been documented as carrying crayfish plague and a large stock of $A$. astacus was lost in 1992 that was thought to have been due to the disease. Astacus leptodactylus was introduced from Poland and Turkey and stocks now occur in many isolated lakes and ponds under private ownership, but there are only a few records from the wild as such.

\section{Egypt}

Procambarus clarkii has been in Egypt since the early 1980s. A.A. HAMADI has been studying the population in the River Nile and reports (Crayfish NEWS, 17 (2), 2, 1995) that it is a highly tolerant invader capable of living anywhere in water and cultivated ground. Nearly every possible site in Giza, Cairo and the Nile Delta is colonised. However, there is little exploitation of the species. 


\section{Estonia}

Astacus astacus is the only species of crayfish present in Estonia and probably migrated into rivers and lakes at the end of the last glacial period. TUUSTI et al. (1993) and SKURDAL et al. (1999) report that since the turn of the century stocks have declined due to crayfish plague, overfishing, poaching and habitat destruction. The species is widespread and is presently found in 250 waterbodies throughout the country. Transplantations to areas where crayfish has been lost have been made and hatcheries for producing juveniles have been set up. Crayfish plague spread to Estonia at end of last century but it had most effect in the 1930s, except on the islands of Saaremaa, Hiimaa and Muha. No NICS have been reported, although A. leptodactylus occurs close to Estonia's borders with Russia and Latvia. Although STAROBOGATOV (1995) and LEWIS (2001) thought that $P$. leniusculus had been introduced, this is not thought to be true (T. TAUGBØL, pers. comm., 2001). HURT et al. (1999) state that $A$. astacus is present in $67 \%$ of 54 lakes investigated, but CPUEs were low and they have disappeared from some former crayfish lakes, probably due to eutrophication and hard winters.

\section{Finland}

Astacus astacus is considered to be indigenous to Finland, although CUKERZIS (1988) states that it was introduced to northern parts. As mentioned above fossils of crayfish are known from the Littorina Period and the first written record goes back to 1558 (SKURDAL et al., 1999; WESTMAN, 1999). Crayfish may have entered Finland across the Karelian Isthmus in the post-glacial period. The first distribution data in 1859 shows A. astacus extending to latitude $62^{\circ} \mathrm{N}$, but stocking since then has extended its range up to the Arctic Circle at $67^{\circ} 30^{\prime} \mathrm{N}$ in Lake Leppäjärvi. Crayfish plague is thought to have entered Finland from Russia in 1893 and is still rife with some 10-20 outbreaks every year; 1000 s of lakes have been affected. Of 74 watercourses where A. astacus lives only 20 have been unaffected. Its present distribution is scattered and in many areas is confined to small headwater localities. Astacus leptodactylus is also considered indigenous, although it was only recorded for the first time in 1977 (WESTMAN et al., 1990). It has been encountered sporadically by fishermen in a few south-eastern border waters, where it may have spread from introductions in the Karelian part of Russia; permanent populations may not have yet developed (WESTMAN, 1991). However, according to a 2002 news flash from the Crayfish Innovation Centre in Finland, and recently seen by the author, a population of $A$. leptodactylus has been confirmed as being present in Lake Kivijärvi in the south east of the country near Lake Saimaa, and uniquely occurs with both $A$. astacus and $P$. leniusculus!

Pacifastacus leniusculus was imported from two Californian lakes in 1967-69 and stocking continued with juveniles from Sweden during 1970-74, then with crayfish produced in Finland in 1980 (SKURDAL et al., 1999; WESTMAN, 1999). In all some 300 waterbodies were stocked and, due to renewed interest in 1993, a further 41 localities were stocked. Most of the stockings were made south of $62^{\circ} \mathrm{N}$, only a few being made in the north, of which Lake Kermajärvi $\left(66^{\circ} \mathrm{N}\right)$ represents the world's most northerly $P$. leniusculus population.

\section{France}

Surveys of the distribution of ICS and NICS in France are carried out periodically, i.e. 1977, 1990, and 1995 by means of a questionnaire (VIGNEUX et al., 1993; CHANGEUX, 1996; VIGNEUX, 1997). A survey carried out in 2001 is currently being processed (T. CHANGEUX, pers. comm.).

Astacus astacus, A. pallipes and A. torrentium are considered indigenous species. These were affected by outbreaks of crayfish plague in many departments between 1876 
and 1884 (ALDERMAN, 1996), but only a few occurrences have been reported since (e.g. MACHINO and DIEGUEZ-URIBEONDO, 1998; NEVEU, 1998a, b, 2000). Although A. torrentium was a species well known in France in the $17^{\text {th }} \mathrm{C}$, in the $19^{\text {th }} \mathrm{C}$ it was only to be found in Alsace, but later became extinct (LAURENT, 1988). Recently, two brooks in the Department of Moselle were found to have populations (FRANCKHAUSER and MACHINO, 2001). Austropotamobius pallipes is widespread in France, occurring in the majority of departments (LAURENT, 1988; VIGNEUX et al., 1993; CHANGEUX, 1996). Austropotamobius pallipes has existed in Lake Geneva (Leman) since the $16^{\text {th }} \mathrm{C}$, but was never common (DUBOIS et al., 1999). It was introduced into the French island of Corsica from southern France in the 1920s and is now abundant in streams in the eastern part (ARRIGNON et al., 1999b). Attempts have been made to restock waters affected by plague in France, and these have come from a variety of sources, e.g. Italy and Spain (LAURENT and SUSCILLON, 1962). Similarly, $A$. astacus, which is close to extinction in Lorraine and Morvan, has been subject to a reintroduction programme using stock from Bavaria, Finland and Yugoslavia (LAURENT and PARIS, 1993). It does not have such a widespread distribution as $A$. pallipes, but, compared to the picture in 1977 , it now occurs in many more departments (CHANGEUX, 1996).

ARRIGNON (1996) and ARRIGNON et al. (1999a) deal with the introduction of NICS into France. Astacus leptodactylus was probably not introduced until 1974. It has been used to stock small lakes, ponds and gravel pits. By 1990 it was recorded in 55 locations in 27 departments, this rose to 43 departments in 1995. Orconectes limosus was introduced between 1911-13 with 2000 individuals imported from Germany. Of the 95 French departments, 87 had O. limosus in 1990 (874 locations), and by 1993 it had reached all but two departments including Corsica. In 1990, Pacifastacus leniusculus occurred in 47 locations in 22 departments since its introduction into central France from Sweden in 1972 and the USA in 1974. In 1995 it occurred in 38 departments. Between 1992-96, 27 new locations were found in central France. In the 1970s, A. leptodactylus, O. limosus and $P$. leniusculus were all introduced into Lake Geneva (DUBOIS et al., 1999). The $P$. leniusculus escaped from an experimental laboratory and have invaded the shores since 1976; they are harvested from the French part of lake. MACHINO (1999) reports that $P$. leniusculus has been introduced into some departments in the Rhône-Alpes and are likely to expand their range at the expense of $A$. pallipes. Procambarus clarkii was introduced in 1974 into western France and by 1990 it had reached 14 locations in 10 departments, by 1995 it had reached 36 departments, particularly marshy and rice area in Brittany and the Camargue.

\section{Georgia}

SKURDAL and TAUGBØL (2001) indicate that $A$. leptodactylus is native to Georgia. ALBRECHT (1983) mentions that $A$. astacus colchicus inhabits a small, completely isolated area in the upper Rion system (Caucasus) to the east of the Black Sea. STAROBOGATOV (1995) also mentions its presence, as A. colchicus.

\section{Germany}

TROSCHEL and DEHUS (1993), TROSCHEL (1997), DEHUS et al. (1999a) and SCHULZ (2000) discuss the distribution of crayfish in Germany. Astacus astacus, A. pallipes and A. torrentium are considered as indigenous species. Astacus astacus is widely spread with 719 populations recorded after 1990 . These are mainly confined to small streams and small lakes without connection to other surface waters. The number of populations is, however, small compared with those before the introduction of crayfish plague, NICS, predatory fish such as eels, and certain agricultural practices, all of which have had a negative impact, although crayfish plague is the most serious threat. By using RAPD markers, SCHULZ (2000) has shown that all populations investigated can be separated, even if only a few kilometres apart. Whether this results from isolation or 
adaptation to specific environmental conditions is not known, but it has implications for conservation management and the design of restocking programmes. Austropotamobius torrentium is restricted to the south, and co-occurs with $A$. astacus in some localities. RENZ and BREITHAUPT (2000) provide more information on its distribution in Germany and other parts of Europe. The higher regions of the Rhine near Cologne and the northern tributaries of the Main and the Danube are the borders of A. torrentium's northern distribution in Germany. Austropotamobius pallipes is restricted to the south-west, where it was first discovered in 1989.

Amongst the NICS, Orconectes limosus is the most widely spread, particularly in the north. It was introduced to the R. Oder system near Berlin in 1880 and then entered western rivers, i.e. Rhine, Weser and Maun via the Elbe-Oder-Rhine-Canal. Astacus leptodactylus occurs mainly in the north and the south. Numerous attempts to stock it have been made, but only lake populations have survived. Pacifastacus leniusculus was introduced from Sweden in the 1960s and also from Austria, but only a few scattered populations (five) occur. It co-exists with $A$. astacus in a few running waters. Procambarus clarkii was introduced for the table market and aquarium trade in 1985, it now occurs as semi-wild populations in the north (one) and south (two), and seems able to tolerate winter ice cover. Procambarus zonangulus was abundant in the aquarium trade about 10 years ago but has not become established in the wild (DEHUS, pers. comm., 2001). DEHUS et al. (1999b) report on a NICS new to Germany, i.e. Orconectes immunis. A population was found in 1997 in small canal in the Rhine Valley near Karlsruhe in the south-west, the originators probably coming from an aquarium. There are now a number of reproducing populations east of the $R$. Rhine.

BOHL (1999) provides more information on the situation in Bavaria, where crayfish distribution has been mapped since 1983. Astacus astacus with 288 populations and A. torrentium with 141 populations occur in all regions, but populations are small and restricted to remote upstream areas. Twelve populations of $A$. leptodactylus, 16 of $P$. leniusculus, 46 of $O$. limosus, and two of P.clarkii are known.

\section{Greece}

According to WESTMAN et al. (1990) A. astacus is indigenous to Greece, whilst A. leptodactylus has been introduced, although SKURDAL and TAUGBØL (2001) list them both as indigenous. In addition, ALBRECHT (1982) mentions the occurrence of A. torrentium in northern Greece. THÉOCHARIS (1986) reported on a crayfish plague outbreak amongst $A$. astacus in north-western Greece in 1982 that coincided with the introduction of $P$. leniusculus from Sweden. The outcome of this introduction is unknown.

\section{Hungary}

According WESTMAN et al. (1990) and PUKY $(2000,2001)$ A. astacus, A. torrentium and $A$. leptodactylus are considered indigenous, although the latter had also been introduced. Orconectes limosus was introduced in 1960 and now occurs in the north and south. It is rapidly spreading in the Danube catchment. Astacus astacus is relatively common in the north and west, although it has disappeared from large areas of its historic range due to crayfish plague (KISZELY, 1999). Austropotamobius torrentium occurs in the north and inhabits mountain streams in the Danube Bend. Astacus leptodactylus also occurs in the north but tends to be a lowland species. It developed considerable populations during the 1900s but its westward spread has slowed down over the last few decades; it has replaced $A$. astacus in many places, particularly in the east (KISZELY, 1999). Austropotamobius pallipes is listed as being present in Hungary by GROOMBRIDGE (1993) but according to Y. MACHINO (pers. comm.) this is incorrect and relates to a time when Hungary included Croatia within its boundaries. 
Iran

Astacus leptodactylus inhabits the southern Caspian Sea along the shores and lagoons of Iran, but so far little exploitation has taken place (MATINFAR, 1999).

Italy

The Italian region of Lombardy was the first area in Europe to be hit by crayfish plague in 1859. Although the disease spread it was confined to north-east Italy and since then there have been no further reports of the disease in Italy (ALDERMAN, 1996).

GHERARDI et al. (1999) show that Austropotamobius pallipes is the most widely spread crayfish, except in the south, Sicily and Sardinia. LÖRTSCHER et al. (1997) recently confirmed the presence of $A$. pallipes in the Pô and Adige rivers and SANTUCCI et al. (1997) used specimens from near the border with Slovenia for their genetic studies. Austropotamobius pallipes is common in north-western Italy (Liguria region) and has been subject to a number of surveys for conservation purposes (e.g. SALVIDIO et al., 1993; SALVIDIO et al., 2002). It occupies different bioclimatic area, i.e. Mediterranean sea coast, Maritime Alps, and the Apennines, at heights ranging from 90-1050 m a.s.l. Astacus astacus, however, occurs only in northern Italy, it is cultured there, but there has been some controversy about where it actually occurs in the wild. The record for the northeast in the Friuli-Venezia-Giulia Region mentioned in several papers (e.g. FROGLIA, 1978; GHERARDI et al., 1999) is not correct (Y. MACHINO, pers. comm.). Astacus astacus is, however, present in the Lago di Santa Anna (Province of Bulluno) (PAGOTTO and PAGOTTO, 1994; DELMASTRO, 2000), and a creek near Gais (Province of Bolzano) (OBERKOFLER, 2000). OBERKOFLER et al. (2002) deal in more detail with the occurrence of $A$. astacus in northern Italy. Austropotamobius torrentium occurs in the northeast in the Slizza River in the Undine region but, according to MACHINO (1996) it is close to extinction.

Procambarus clarkii was introduced from Kenya in 1983 (WESTMAN et al., 1990) and is cultured mainly in central parts, it is well established in the wild in northern and central regions (DELMASTRO and LAURENT, 1997; BARBARESI and GHERARDI, 2000). It is undergoing great expansion in some sections of the Pô River drainage basin in western Piedmont (DELMASTRO and LAURENT, 1997; DELMASTRO, 1999). It is widespread in Tuscany, especially in the large Massaciuccoli Lake, whose population originates from the dumping of the stock of a crayfish farm that went bankrupt in 1993 (BARBARESI and GHERARDI, 2000). Orconectes limosus is cultured on only one farm but is now widespread in the wild in central and northern parts since its introduction in 1991, particularly in the R. Pô drainage system and in central Italy (DELMASTRO, 1992; DELMASTRO and LAURENT, 1997; DELMASTRO, 1999). Astacus leptodactylus is not that common in the wild but it occurs in north and central parts, and is cultured on a few farms. Pacifastacus leniusculus is cultured in the north and very south, where other crayfish don't occur. The only record for the wild is in the Adige River system in the north (MACHINO, 1997a). Both Cherax destructor and C. quadricarinatus are cultured in northern and central Italy (D'AGARO et al., 1999), but neither has become established in the wild.

FÜREDER and MACHINO (1999) have studied the crayfish of South Tyrol (Italy) and they give a lot of historical information about previous records. They consider $A$. pallipes to be indigenous to the area. Pacifastacus leniusculus was introduced 1981 from Austria but had previously been identified as $A$. astacus (MACHINO, 1997a). It may have led to the disappearance of $A$. pallipes in some areas. FÜREDER et al. (2001) reckon that due alteration and degradation only 15 standing and running waters now contain crayfish (A. pallipes, $A$. astacus, $O$. limosus and $P$. leniusculus) in South Tyrol. 


\section{Kazakhstan}

Both Astacus pachypus (as Caspiastacus pachypus) and Astacus leptodactylus (as Pontastacus leptodactylus eichwaldi) occur in the coastal waters of the Caspian Sea off Kazakhstan (CHERKASHINA, 1999a, b; SOKOLSKY et al., 1999). STAROBOGATOV (1995) states that he has seen the syntypes of $A$. kessleri in Russian museums and that they came from the town of Turkestan in southern Kazakhstan. ALBRECHT (1983) considers kessleri to be a subspecies of $A$. leptodactylus.

\section{Latvia}

SKURDAL et al. (1999) report that the last data available for Latvia is for the 1960s, when $A$. astacus was registered in 117 lakes in 1967, and A. leptodactylus in 36 lakes in 1968, mainly in the south east. Astacus leptodactylus may have invaded the country from stockings via Belarus. Crayfish plague outbreaks were reported in the 1890s. STAROBOGATOV (1995) states that $P$. leniusculus has been introduced and this has been confirmed by TAUGBØL (pers. comm.) who visited Latvia in 2001. The introduction was only into one or two lakes in the Sigulda National Park (north of Riga) in 1983, but they do not appear to have spread. TAUGBØL also confirmed that $A$. astacus was widely spread, and that $A$. leptodactylus occurs mainly in the north-eastern and southern parts.

\section{Liechtenstein}

According to BOHL (1997), historical notes indicate that crayfish, probably $A$. astacus and $A$. torrentium, were present in the 1800 s, but have since been eliminated by crayfish plague. Astacus astacus exists at one site as the result of an introduction in 1980 , and $A$. pallipes was implanted into ponds in 1995. Liechtenstein is surrounded by countries with NICS, but none have been reported as having become established in this country.

\section{Lithuania}

BURBA (1999) and SKURDAL et al. (1999) state that $A$. astacus was cited as being present as far back as 1578 and that Lithuania was one of the most important centres in Europe for crayfish exports in early 1900s. However, crayfish plague affected stocks in 1886 and the disease has been found in 31 lakes. Crayfish plague, pollution, physical encroachment and eel stocking have all contributed to a decline in stocks. In 1992 A. astacus existed in 214 locations in 36 out of 44 regions. At the start of the 1900 s several lakes were stocked with $A$. leptodactylus, probably imported from Latvia and/or Belarus. In 1983 they existed in over $8 \%$ of crayfish localities, and in about half existed with $A$. astacus. Astacus leptodactylus was found in 22 localities and in 11 out of 44 regions, mostly in the north east of the country. In 1972 P. leniusculus was introduced from Sweden and stocked in two isolated lakes; it is now found in 10 localities in the mid-eastern part. The presence of . limosus, originating from Poland, was confirmed in 1995, and it is now present in 10 localities in three regions in the south and west.

\section{Luxembourg}

ARRIGNON et al. (1999a) and TROSCHEL (1999) report that $O$. limosus occurs at a number of localities, particularly in the R. Mosella on the borders with France and Germany, where it invaded from the R. Rhine or the upstream catchment of the R. Moselle. It has also been introduced into the Ober-Sauer-Staaussee reservoir in the north west of the country. Pacifastacus leniusculus was introduced from 1972-78 to replace A. astacus devastated by crayfish plague and is now well established in some reservoirs, lakes and 
rivers. Astacus astacus was introduced into the R. Our, but according to Y. MACHINO (pers. comm., 2002) this has not become established. Austropotamobius torrentium is rare and almost extinct. However, MACHINO $(2000,2001)$ found it living with A. leptodactylus in one small brook, and in the Rounderbaach and Etang de Lucien (Grevenmacher).

\section{Macedonia}

BUDHINA (1989) states that $A$. torrentium macedonica and $A$. colchicus are present in Macedonia. ALBRECHT (1983) considers A. colchicus to be a subspecies of $A$. astacus.

\section{Moldova}

Y. MACHINO (pers. comm.) has communicated to this author that both A. astacus and $A$. leptodactylus are present.

\section{Morocco}

MELHAOUI (1988) (Crayfish NEWS, $10(4), 7)$ reports that A. astacus and $O$. limosus have been introduced and are present in the middle Atlas Mountains of Morocco (North Africa).

\section{Netherlands}

ADEMA (1989) reports that $A$. astacus, A. leptodactylus, O. limosus, and P. clarkii are present in the wild. Pacifastacus leniusculus has also been introduced from hatcheries in Belgium. Astacus astacus is thought to be almost extinct. After 1975 it was found in a few localities in the east but in 1989 only one population was found near Arnhem. Astacus leptodactylus was introduced from Turkey in 1977 and is now common in the east and west. Orconectes limosus was discovered in 1968 and is now common in most of the country. VAN DER VELDE et al. (1998) state that O. limosus entered the Netherlands via the R. Meuse from Belgium, as well as from Germany via the Twenthe Canal. One of the few studies carried out on this species in Europe was by BRINK et al. (1988) on O. limosus occupying Dutch rivers. Procambarus clarkii was imported from Kenya and is often sold in fish markets in the west of the country, however, it is common in the wild as reported to the author, where large specimens were seen walking in wet grass, close to ponds and ditches in the nature reserve « Het Hol » near Kortenhoef (P. NÖEL, pers. comm., 2001).

\section{Norway}

Unlike most countries in Western Europe, Norway has only one crayfish species, $A$. astacus, which may have been introduced from Sweden in ancient times (WESTMAN et al., 1990; SKURDAL et al., 1999). However, written records go back to 1752 for a locality $150 \mathrm{~km}$ from the Swedish border in a watercourse that drains into the sea close to Oslo (J. SKURDAL, pers. comm., 2001). Most current populations are probably the result of stocking. It is mainly distributed in the south-eastern part of the country, with some scattered populations along the coast as far north as Trondheim. In the 1990s it was recorded from 365 out of 577 suitable watercourses. It is very abundant in some localities and is extensively harvested, e.g. Lake Steinsfjorden (SKURDAL and TAUGBØL, 2001), which is one of the best-documented populations in Europe (SKURDAL et al., 2002). Crayfish plague struck Norway in 1971 in two small waterbodies on the border with Sweden. In 1987 the disease reappeared and there have been a number of outbreaks since 1993. Currently there are no NICS in Norway, although P. leniusculus occurs in Swedish river systems draining from Norway. 


\section{Poland}

Astacus astacus is considered indigenous, with $A$. leptodactylus being introduced from Russia at the turn of the $20^{\text {th }} \mathrm{C}$, and $O$. limosus from Germany in the 1890 s (WESTMAN et al., 1990). However, STRUŻYŃSKI and ŚMIETANA (1999) consider $A$. leptodactylus to be indigenous. They also state that the distribution of $A$. astacus and A. leptodactylus is patchy and scattered, although $A$. astacus is relatively common in southeastern parts, and $A$. leptodactylus along the borders with Belarus and the Ukraine. According to STRUŻYŃSKI and ŚMIETANA (1999) Poland was one of the biggest exporters of $A$. astacus between 1924-39, but reductions in stocks have occurred due to the same factors affecting other European countries, and some of best producing regions were lost due to boundary changes after WWII.

JAŹDŹEWSKI and KONOPACKA (1998) discuss the introduction, and then the spread of O. limosus in Poland from 1953 through to 1998, whence it had reached the south-eastern part of the country. They also mention attempts to introduce $P$. leniusculus from Sweden into north-eastern areas in the 1970s and early 1980s. STRUŻYŃSKI and ŚMIETANA (1999) mention that $P$. leniusculus is restricted to only a few water bodies of the Mazurskie Lakeland and the Pomorskie Lakeland, but that $O$. limosus occurs in $75 \%$ of Polish territory. ĎURIŠ (1999) carried out a crayfish survey and found only O. limosus at the 19 sites he examined throughout the country. STAROBOGATOV (1995) lists A. torrentium for Poland but Y. MACHINO (pers. comm.) believes this to be in error.

\section{Portugal}

ALBRECHT (1983) quotes MATEUS (1937) as saying that $A$. pallipes did not reach Portugal until 1931. However, the origin of Portugal's so-called indigenous crayfish, $A$. pallipes, is uncertain. An enigmatic record exists for 1797, but the crayfish was not " rediscovered » until 1931 (ALMAÇA, 1990). BERNARDO et al. (2001a) refer to it as the indigenous species. MACHADO (1931) states that Astacus fluviatilis (= A. astacus) is present, and this was taken up by CUKERZIS (1988). However, its presence has not been verified.

Whatever its origin, by the middle of the 1970s three distinct populations of A. pallipes were living in north-east Portugal and the R. Cértima and R. Sever. However, the results of fieldwork in 1985 suggest that $A$. pallipes in the R. Cértima may have been eliminated by pollution and eutrophication. In the R. Sever crayfish were common in 1977 but were not found in 1984. BERNARDO et al. (1997, 2001b) and GUTIÉRREZ-YURRITA et al. (1999) state that $A$. pallipes has suffered considerable reduction in range and abundance over the last two decades due to environmental degradation, critical climatic conditions, and crayfish plague. It was confined to a few small areas in the north-eastern part of the country (Azibo and Tortulhas rivers), but none were found in 1999 (BERNARDO et al., 2001a), and it may now be extinct according to Y. Machino (pers. comm., 2002).

Procambarus clarkii arrived in 1979 as a result of natural expansion of the population that had become established in Spain, and which has since spread to most inland waters where it has replaced $A$. pallipes in some rivers. In the late 1970 s some stockings (using French stock) were made to try and extend the distribution of $A$. pallipes. In the early 1980 s some stockings appeared to have been successful but by 1986 had largely disappeared. There was a possible outbreak of crayfish plague in 1986 in north-eastern rivers that caused mass mortalities. Procambarus clarkii has also become established on São Miguel Island in the Azores (CORREIA and COSTA, 1994). Pacifastacus leniusculus has also been reported to be invading the R. Maçãs in Quintahilla in Portugal after having been stocked in tributaries of the same river in Spain (BERNARDO et al., 2001a). 


\section{Romania}

CUKERZIS (1988) states that $A$. astacus lives in the north-eastern part of the country. SKURDAL et al. (1999) list $A$. astacus and $A$. leptodactylus as indigenous for Romania, but there is no recent information on their distribution. Y. MACHINO (pers. comm.) is of the opinion that $A$. torrentium also occurs there.

\section{Russia}

FEDOTOV et al. $(1993,1998)$ state that a large proportion of lakes and rivers in north-western Russia are occupied by $A$. astacus particularly in the Pskov region and south west of St Petersburg. However, pollution is a threat to many stocks and crayfish plague hit stocks near St Petersburg in 1987. In the river basins of the West Dvina and the Veilkaya, 10 lakes and four rivers were found to have $A$. leptodactylus. Orconectes limosus (from Poland) and $P$. leniusculus (from Lithuania) have been introduced into Kaliningrad and have become well established; $A$. astacus and $A$. leptodactylus are considered indigenous to this area but are now virtually absent. An attempt was made to introduce $P$. leniusculus to the north-west in the Lenigrad and Pskov regions of Russia, but this was unsuccessful. It was also introduced to the Cheljabinsk region south of Siberia from Lithuania in 1976 but there have been no reports of whether it became established or not (V. FEDOTOV, pers. comm., 1998).

CUKERZIS (1988) quotes MALYSHEV (1984) as recording an introduction of $A$. astacus into the tributaries of the $\mathrm{R}$. $\mathrm{Ob}$ in Siberia to the east of the Ural mountains. The outcome of this introduction is unknown.

ALEXANDROVA (1999) reports that Pontastacus leptodactylus (= A. leptodactylus) is one of the most wide-spread species in Russia, including Central Russia situated in the upstream and middle-stream Volga River basin (the Caspian Sea basin). Pontastacus leptodactylus leptodactylus is present in harvestable quantities in the north west and north east of Central Russia. It can be distinguished from $P$. leptodactylus boreoorientalis from the Kama River basin. Pontastacus leptodactylus leptodactylus inhabits lakes and streams of the Volga river system and its tributaries. It has found its way into the Baltic basin rivers, e.g. Msta and Zapadaya Dvina, that have their sources in the Twer Region in the north west of Central Russia, via canals that connect the rivers running into the Caspian and Baltic. It inhabits several water-bodies of the Baltic Sea and Gulf of Finland that had previously been inhabited by $A$. astacus, although sometimes they can be found together.

MIKOUIZA et al. (1999) state that the crayfish area of the Volga-Caspian region extends from the north to the south for more than $1500 \mathrm{~km}$. Astacus leptodactylus leptodactylus, A. leptodactylus eichwaldi and A. pachypus inhabit different climatic zones and have specific features. SOKOLSKY et al. (2000) report that Pontastacus leptodactylus leptodactylus and P. eichwaldi eichwaldi (note change in terminology, see Table I) are present in the Astrakhan region of Russia, and populations have been exploited for about 100 years. In some years the harvest has reached 130 tonnes in the Volga-Akhtubinsk flood-lands, in the delta and in the front of the Volga River, however, nowadays only about 20 tonnes are caught due to poor organization.

CHERKASHINA (1999a) indicates that Caspiastacus pachypus (= Astacus pachypus) is in the River Don and the Dneiper-Bug Lagoon of the AzovBlack Sea Basin. CHERKASHINA (1999b) states that Pontastacus cubanicus (= Astacus leptodactylus cubanicus) is commercially important in the waterbodies of the lower R. Don area of Russia, i.e. in the R. Don itself, the R. Seal with its tributaries, and the Ust-Manychskoye, Veselovskoye and Proletarskoye reservoirs. 


\section{Slovakia}

According to P. URBAN of the Otter Conservation Project, $A$. astacus, A. torrentium and $A$. leptodactylus (only in the Danube) are found in Slovakia (information via J.E. SKELTON, pers. comm., 2000). ĎURIŠ (1989) also mentions that $A$. torrentium has been found in Danube River near Bratislava. GROOMBRIDGE (1993) lists A. pallipes as being present but this is probably in error according to Y. MACHINO (pers. comm.).

\section{Slovenia}

BUDHINA (1989) reports that $A$. astacus, $A$. torrentium and $A$. italicus ( $=$ A. pallipes) are present in Slovenia but that population densities are low due to the effects of crayfish plague. Astacus astacus occurs all over the Danube river basin, except in the area of the Adriatic where $A$. italicus is present in coastal rivers. Austropotamobius pallipes is distributed in the same area as $A$. astacus except in the north-eastern part of the country, where A. astacus has been introduced. According to MACHINO (1997c) Slovenia was the second most productive region for crayfish in the former Habsburg Empire in the early 1900 s. He has recently found $A$. pallipes in the Mediterranean drainage basin and A. torrentium in the Danube drainage basin. Astacus astacus was found in both drainage systems. SANTUCCI et al. (1997) used $A$. pallipes from Slovenia during their genetic studies, as did GRANDJEAN et al. (2001a), although in the latter case their map indicates a point in Croatia by mistake.

\section{Spain}

Like Portugal the origin of $A$. pallipes, the so-called indigenous species, is uncertain. ALBRECHT (1983) was of the opinion that crayfish did not originally occur in Spain and refers to a reference from 1642 stating that they were absent. HUXLEY (1881) notes that A. nobilis (=A. astacus) was said to live in the region of Barcelona, but earlier he mentioned that crayfish similar to the English species (now known to be $A$. pallipes, not A. torrentium as thought by HUXLEY) had in fact been seen by him from the vicinity of Madrid. HOLDSWORTH (1880) also reports crayfish from a number of rivers to the north east of Madrid (R. Henares, R. Jalon and a tributary of the R. Duero), but says he could not find them elsewhere. BALSS (1925) suggested a natural occurrence for crayfish he found in Guadiana, a long way south of Madrid.

GRANDJEAN et al. (2001a) found a very low genetic variation among Spanish populations of $A$. pallipes, but a similarity with one population in Italy. They suggest this could be due to a founder effect related to an anthropogenic origin of crayfish in Spain, possibly from Italy. Alternatively, the lack of genetic variation could be the consequence of a drastic bottleneck during the Pleistocene, the modern day populations having arisen from a single refugium from that time. As another explanation, both Spanish and Italian populations could be the relicts of an extinct intermediate population located in France, which extended their range, either by stream captures after glaciation periods, and/or by translocations by humans. SANTUCCl et al. (1997) also found two populations in Spain that appeared to be closely genetically related to populations in the north Apennines (Italy).

GUTIÉRREZ-YURRITA et al. (1999) consider A. pallipes to be indigenous to Spain. They give comparative maps showing its decline from 1960s, when it was abundant in many areas, to the 1990s when it has become scarce and largely restricted to northern parts. Many factors have contributed to this decline - climatic conditions (drought), canalisation, clearing, dredging and embanking rivers, changes to river beds, construction of reservoirs, regulation of water levels and stream flows, pollution, large-scale overexploitation, crayfish plague, and the introduction of NICS. ALONSO et al. $(2000,2001)$ state that less than 1000 small sized populations of $A$. pallipes survive in northern and north-eastern Spain and occupy marginal areas, frequently cut off from the main river 
systems. Some areas of Spain are subject to restocking and protection plans for A. pallipes in an attempt to restore the species (e.g. DIÉGUEZ-URIBEONDO et al., 1997). GARCÍAARBERAS and RALLO (2000) have shown that A. pallipes is still present in areas of the Basque Country where it was thought to have become extinct.

Crayfish plague probably did not arrive in Spain until 1956, possibly related to the introduction of $A$. leptodactylus from Germany, although the plague fungus was never identified (ALDERMAN, 1996). The first positive identification of the fungus was not until 1978 from the $\mathrm{R}$. Riaza, again probably originating from imported $A$. leptodactylus (ALDERMAN, 1996).

A number of species have been introduced into Spain: Astacus astacus into central Spain in 1963-64, but without success; Procambarus clarkii from Louisiana into southern Spain in 1973 and 1974, with great success and now widely spread, although $P$. zonangulus introduced with it did not become established; Pacifastacus leniusculus from Sweden into central Spain in 1974, became successfully established; Astacus leptodactylus from Turkey in 1975, without success (contrary to the list of SKURDAL and TAUGBØL, 2001); O. limosus is reported to have been introduced but has never been found in the wild; Cherax destructor from Australia to northern Spain in 1983 where it has been successful in its area of introduction (Zaragoza). Procambarus clarkii has also been successfully introduced into Majorca (Balearics) and Tenerife (Canary Islands). GUTIÉRREZ-YURRITA and MARTINEZ (2001) give details of the expanding population of $P$. clarkii in the Barranco de San Andres on Tenerife Island, where they were probably introduced in 1996/97. CARRAL et al. (1993) report on attempts to introduce $P$. leniusculus as a replacement for $A$. pallipes in some areas. In some cases this is being done to stop the advance of $P$. clarkii (CUELLAR and CUELLAR, 2000). DIÉGUEZURIBEONDO et al. (1997) report that $P$. leniusculus and $P$. clarkii are thriving in the Navarra region (N.W. Pyrenees).

\section{Sweden}

SKURDAL et al. (1999) state that fossil crayfish have not been found in Sweden (unlike in Finland) and it is not clear whether $A$. astacus was ever indigenous. Extensive stocking over the last 500 years has extended its range northwards to include mainly running waters along the east coast all the way up to the Finnish border. In $1996 \mathrm{~A}$. astacus was reported from 943 lakes, 356 running waters and 297 ponds mainly in the southern one-third of the country. Crayfish plague arrived with a shipment of crayfish from Finland in 1907 and decimated stocks. In addition, acidification, water pollution and fluctuation in water regimes have contributed to its decline. EDSMAN (2000) estimates that Sweden had 30000 populations of $A$. astacus at the turn of $20^{\text {th }} \mathrm{C}$ but that only $5 \%$ of these remain a 100 years later. Interestingly, EDSMAN et al. (2002) explored genetic variation in 15 populations of $A$. astacus and found most, but not all, genetically distinct, as did SCHULZ (2000) in some German populations.

BRINCK (1977) and SVÄRDSON (1995) provide historical accounts of crayfish introductions into Sweden. Initially there were requests to introduce $O$. limosus from Germany by a private individual in 1956 and subsequently. Despite intense lobbying his applications were shelved, but it was decided in 1959-60 to allow the introduction of $O$. virilis from Lake Michigan and P. leniusculus from the Sacramento River in North America. The $O$. virilis introduction was not successful and did not reproduce in 1960. However, in 1960 the $P$. leniusculus survived well and reproduced and was subsequently introduced into a number of lakes. STURE ABRAHAMSSON persuaded RUBEN RAUSING, the founder of Tetra Pak, to finance a special crayfish hatchery at Simontorp (ABRAHAMSSON, 1973a, b). This needed a large quantity of broodstock and these were imported from Lake Tahoe in California. In addition to Simontorp, private farmers were also 
allowed to import and in 1969 some 67 natural waters were stocked. SKURDAL et al. (1999) report that in $1996 P$. leniusculus was to be found in 2697 localities - 1042 lakes, 319 running waters, 1336 ponds, but they consider that this is probably an underestimate due to illegal stockings. Pacifstacus leniusculus is found in most of southern Sweden north to the Dalälven river system, two records north of this system also occurs on the islands of Gotland and Öland (EDSMAN, 2000).

\section{Switzerland}

WESTMAN et al. (1990) state that $A$. pallipes and $A$. torrentium are considered indigenous, and that $A$. astacus may have been introduced, but may also be indigenous to some areas. STUCKI and STAUB (1999) report that $A$. astacus is found in many ponds, lakes, rivers and brooks. It often occurs with $A$. leptodactylus in lakes. Its distribution has been highly modified by man. Austropotamobius torrentium occurs in many brooks in the north-eastern part of the country, and also in L. Ägeri in low densities. Austropotamobius pallipes lives in brooks, canals and ponds in western areas and in the valleys of the alpine region. It can also be found in mountain lakes up to an altitude of $1000 \mathrm{~m}$ where it has been introduced. It may occur in some western lakes but has disappeared from Lakes Neuchâtel, L. Murton and parts of L. Geneva. VIELLE (1996) reports that many canals of the R. Rhône valley were populated by A. pallipes until 1950, but since then modified hydrology after reservoir construction, water pollution, and possibly outbreaks of crayfish plague, have considerably reduced the populations. In 1995 a population was found in a canal polluted by industrial wastes and oil coming from an airport in the Canton du Valais. LÖRTSCHER et al. (1997) have confirmed the continued presence of $A$. pallipes in the R. Rhine and R. Rhône. They suggest that $A$. pallipes stocks may have been transplanted from the Pô river system in Italy over the Alps and into the upper Rhône and upper Rhine by man as a food source, and that this may explain present day distribution patterns. STUCKI and JEAN-RICHARD (1999) provide detailed maps of the distribution of $A$. astacus, $A$. pallipes and $A$. torrentium in Switzerland.

Astacus leptodactylus, introduced after 1972 (WESTMAN et al., 1990), is present in many lakes and ponds in the lower parts of Switzerland, often at high density. Orconectes limosus, also introduced after 1972 (WESTMAN et al., 1990), forms strong populations in western lakes and in L. Sihl and L. Laurerz, and in some rivers, e.g. R. Aare and R. Rhone, as well as L. Constance and L. Lugano. Pacifastacus leniusculus is found in L. Geneva and in two ponds in the north. It is also found in south-western Switzerland, and with $O$. limosus in the R. Aare. Procambarus clarkii is found in four ponds in the north, in one it occurs with $P$. leniusculus. Despite $P$. clarkii and $P$. leniusculus occurring in brooks draining into L. Zurich, no colonisation of the lake itself appears to have occurred, although $P$. clarkii has been observed migrating upstream. DUBOIS et al. (1999) report that A. leptodactylus and $O$. limosus are known from the Swiss side of Lake Geneva. STUCKI and JEAN-RICHARD (1999) provide detailed maps of the distribution of A. leptodactylus, $O$. limosus, $P$. leniusculus, and $P$. clarkii in Switzerland.

\section{Turkey}

KÖKSAL (1988) summarizes the distribution of $A$. leptodactylus, the only indigenous crayfish to Turkey. BOTT (1950) first identified $A$. leptodactylus from Kayseri, Bursa and Istanbul. Two subspecies are present, i.e. A. I. leptodactylus (found in Íznic, Terkos, Çivril and Tunca lakes, Meriç River, and Cori and Gelemen streams) and $A$. I. salinus (found in the Manyas, Eğridir, Beyşehir, Apolyont, Eber, Akşehir, Gölcük lakes and Miliç Brook). STAROBOGATOV (1995) is of the opinion that populations of the subspecies salinus in Turkey probably belong to the species Pontastacus intermedius (see Table I).

Turkey was a major supplier of crayfish to West European markets but stocks were badly hit by crayfish plague in the mid-1980s (BARAN and SOYLU, 1989; HOLDICH, 1993; 
ALDERMAN, 1996). NICS appear to not to have become established yet, and there has been a modest recovery of stocks in some previously devastated lakes south of Bursa, but other lakes that had been the highest producers have yet to recover (P. BAGOT, pers. comm., 2001).

STAROBOGATOV (1995) mentions that $A$. colchicus may be found in the vicinity of Istanbul, and that it has been introduced into the R. Kura in eastern Turkey. ALBRECHT (1983) considers colchicus to be a subspecies of $A$. astacus. Its presence in Turkey is therefore a possibility, but there have been no recent confirmations.

\section{Turkmenistan}

CHERKASHINA (1999a) indicates that Caspiastacus pachypus (= Astacus pachypus) occurs in coastal waters off Turkmenistan, and SOKOLSKY et al. (1999) show that Pontastacus leptodactylus eichwaldi (= Astacus leptodactylus eichwaldi) has a similar distribution.

\section{Ukraine}

CHERKASHINA (1999b) records Caspiastacus pachypus (= Astacus pachypus) for the Dneiper-Bug Lagoon of the Azov-Black Sea Basin that is part of the Ukraine. KÖKSAL (1988) states that $A$. leptodactylus leptodactylus and $A$. I. salinus coexist in the Ukraine. CUKERZIS (1988) mentions that $A$. astacus has been introduced to eastern parts of the country. STAROBOGATOV (1995) lists A. torrentium for the Ukraine, but Y. MACHINO (pers. comm.) believes this to be in error.

\section{Uzbekistan}

ALBRECHT (1983) mentions that there is an isolated population of $A$. leptodactylus in Tashkent to the east of the Aral Sea. The species there has been referred to as A. kessleri, but he considers it to be merely a variety of $A$. leptodactylus. STAROBOGATOV (1995), however, refers to it as Pontastacus kessleri.

\section{Yugoslavia (Republics of Montenegro and Serbia)}

WESTMAN et al. (1990) state that $A$. astacus, A. leptodactylus, $A$. pallipes and $A$. torrentium are indigenous to the former Yugoslavia. However, it is not clear which of these species occur in the lands now considered to be Yugoslavia. BUDHINA (1989) said that $A$. torrentium occurred in all of the former Yugoslavia, including Montenegro that is in the new Yugoslavia. LAURENT (1988) states that $A$. torrentium is the most frequently encountered crayfish throughout the R. Danube catchment, part of which runs through Yugoslavia. BUDHINA (1989) also states that $A$. astacus occurs in Montenegro, and this was confirmed by EDSMAN (pers. comm., 2001), who said that several tonnes a year are exported live to Sweden.

\section{THE FUTURE}

Although stocks of indigenous crayfish in many European countries have yet to reach pre-plague levels, in the author's opinion their current status is relatively good if viewed at a European level. That is not to say, however, that ICS are not under threat from human actions, climate, crayfish plague and NICS in certain countries, and in some cases may even be on the verge of extinction, e.g. A. pallipes in Portugal and A. astacus in the Netherlands. Many European countries have large stocks of $A$. astacus and $A$. pallipes, and even $A$. torrentium is common in some countries. Stocks of Astacus leptodactylus and A. pachypus are also large in some East European countries. Predictions about the demise of ICS in Europe are hopefully premature. 
A case in point is Britain where, in the 1980s there were predictions that the socalled indigenous crayfish, Austropotamobius pallipes, could become extinct due to the actions of crayfish plague and Pacifastacus leniusculus. Populations have been badly affected, but the perceived threat led to a much greater interest in the species and much more work was carried out on them (e.g. HOLDICH et al., 1995). They were discovered to be more abundant than previously thought and new populations are still being discovered due to more intensive survey work! Crayfish plague outbreaks still occur but none were recorded between 1994 and 1998 - unfortunately, one was recorded in 1999 and another in 2000. The disease has not killed off a lot of the stock and there are still many large populations in a variety of waterbodies. Legislation has been introduced to protect $A$. pallipes in Britain and this has had the effect of not only by curtailing the spread of crayfish plague and NICS, but also protecting the species from human activities such as repairs to bridges and weirs, dredging, road building, pipe laying, etc.

From the papers the author has read in preparation for this review what is outlined above appears to be happening in many countries in Western Europe, but unlike in some countries, e.g. France and Spain, very little restocking is being done in the British Isles, although that which has been done has been successful (e.g. REYNOLDS et al., 2000; SPINK and FRAYLING, 2000). As pointed out by SCHULZ (2000) and REYNOLDS et al. (2002a) the genetic structure of a population has implications for conservation management and the design of restocking programmes. It is important, therefore, that the genetic composition of the donor population is known. In Germany (SCHULZ, 2000) and Sweden (EDSMAN et al., 2002), genetic variation was found between most populations of A. astacus. Similarly, GRANDJEAN and SOUTY-GROSSET (2000) found variation amongst populations of $A$. pallipes in southern France, but not between populations in northern France and the British Isles.

Officials in the majority of countries in Western Europe carry out surveys of crayfish distribution from time to time and produce detailed maps for a given time period. These are often based on questionnaires with very few regular field surveys being carried out using trained personnel, and, if they do, the time period between surveys is often too long. Ideally, surveys should be carried out at least every third year, particularly considering the speed at which some NICS can spread - the situation is dynamic and needs regular surveillance. If caught early enough it may be possible to control an unwanted fledgling population, but this is very difficult once it becomes established (HOLDICH et al., 1999a). Often crayfish are recorded during routine surveys of the freshwater environment as part of water quality control programmes, as in England and Wales (SIBLEY et al., 2002), but do the observers always know which species they are recording? The same can be said of questionnaires when a number of crayfish species could be present, e.g. France, Italy and Switzerland have seven species, whilst Germany has eight! Obviously, education is a key to this as it is usually too expensive to send out trained personnel on a regular basis. A number of countries have produced identification leaflets for use by the public as well as by trained personnel, e.g. Austria, Britain, France, Germany, Italy and Sweden, and others should do the same. However, if one was to accept the plethora of species and subspecies listed by STAROBOGATOV (1995) such monitoring would be an impossible task!

TAUGBØL and SKURDAL (1999) have described two scenarios for the future, i.e. 100 years ahead, for ICS in Europe. First, virtually all watersheds suitable for crayfish are inhabited by NICS, and only a few populations of ICS survive in protected localities. Second, there are still countries free from NICS as they are today, e.g. Estonia, Ireland and Norway, and in most countries there are numerous, viable populations of ICS that are considered as valuable, and which are protected by the authorities as well as local people. (To this can be added many countries in Eastern Europe where NICS have not yet been introduced). In order to achieve the second scenario TAUGBØL and SKURDAL (1999) recommend that: where necessary aquatic habitats are restored to make them more suitable for crayfish; ICS are protected at a national level by enforcing legislation; 
knowledge is obtained on the distribution and abundance of stocks; regular monitoring is carried out; indigenous crayfish areas are established in all countries, as required by the European Habitats Directive (i.e. Special Areas of Conservation) for protected species; further spread of NICS is prevented by means of legislation, and co-operation and coordination between different authorities; indigenous crayfish populations eradicated by crayfish plague be re-established; the public is kept informed by means of information leaflets; that a more balanced view is taken when considering non-indigenous species, as they provide a valuable resource in some countries. TAUGBØL and SKURDAL (1999) also make the point that exploitation and protection are closely linked, as those who exploit may also be concerned about the exploited resource. They suggest that if local people are allowed to catch crayfish they will also have an interest in protecting the crayfish population against extermination. This may be so, but the public may also just be satisfied to have crayfish as part of their freshwater fauna and, if educated, accept that it is a protected species in their country.

Considering what has happened in some countries it is surprising that introductions of NICS are still being carried out! North American ecologists are quoting what has happened to ICS in Europe to try and get protection for their ICS from NICS (many from within North America) (LODGE et al., 2000a, b). How often is a risk assessment exercise carried out before a crayfish introduction? Introductions into one country can have an impact on an adjoining country, but how much co-operation is there between countries over such a matter? A case in point is the invasion of Portugal by $P$. clarkii and $P$. leniusculus from Spain, introductions of both species having been made close to the border between the two countries. How often does a crayfish plague outbreak in one country become known to bordering countries? If a database with accompanying maps of the occurrences of ICS, NICS and crayfish plague outbreaks was instigated and continually updated, then this would give managers a much better idea as to what was going on. With the cooperation of interested parties this could be done. The feasibility of such a project is currently being investigated by the author and Pierre NÖEL of the Natural History Museum in Paris.

\section{CONCLUSIONS}

The taxonomy of ICS in Europe needs sorting out so that everybody accepts the same system. In particular it needs to be determined whether or not the Astacus leptodactylus species complex should be given a separate generic status from Astacus astacus, i.e. Pontastacus. Similarly, the taxonomy of Austropotamobius pallipes species complex should be stabilized, particularly with regard to the subspecies, italicus, lusitanicus, pallipes.

Risk assessments should be carried out by all those considering introducing NICS into their countries to determine the potential damage to the freshwater environment, as well as to ICS in their and neighbouring countries. There is plenty of information from other countries on which to base such assessments.

Education of the public as well as those involved in surveying the freshwater environment should be part of any management scheme to protect ICS.

Although distributional information for ICS and NICS is available for many countries this is only for limited time periods. There is a need for more regular surveillance by experts in the field.

A Europe-wide mapping scheme should be implemented so that managers can get a better idea of the range of ICS and any potential threats to them from NICS. Details of 
crayfish plague outbreaks should also be made more available. These two points will be particularly important in preventing the further demise of ICS in Europe.

The preceding four statements are similar to those recommended by McNEELY et al. (2001) in their Global Strategy on Invasive Alien Species.

\section{ACKNOWLEDGEMENTS}

The author would like to thank all those people who provided him with information on crayfish distribution, especially to Yoichi MACHINO for his frequent correspondence and for visiting me in England, and to Julian REYNOLDS and Andréanne DEMERS for the French where needed.

\section{REFERENCES}

ABRAHAMSSON S., 1973a. The crayfish Astacus astacus in Sweden and the introduction of the American crayfish Pacifastacus leniusculus. Freshwater Crayfish, 1, 27-40.

ABRAHAMSSON S., 1973b. Methods for the restoration of crayfish waters in Europe - The development of an industry for the production of young Pacifastacus leniusculus Dana. Freshwater Crayfish, 1, 203-210.

ACKEFORS H., 1999. The positive effects of established crayfish introductions in Europe. In : Crayfish in Europe as alien species. How to make the best of a bad situation? GHERARDI F., HOLDICH D.M. (Eds.), 49-61, A.A. Balkema, Rotterdam.

ADEMA J.P.H.M., 1989. De verspreiding van rivierkreeften in Nederland. Nieuwsbrief European Invertebrate Survey - Nederland, 19, 3-10.

ALBRECHT H., 1981. Die Flusskrebse des westlichen Kärnten. Carinthia II, 171./91. Jahrg., 267-274. Klagenfurt.

ALBRECHT H., 1982. Das System der europäischen Flusskrebse (Decapoda, Astacidae): Vorschlag und Begründung. Mitt. hamb. zool. Mus. Inst., 79, 187-210.

ALBRECHT H., 1983. Besiedlungsgeschichte und ursprünglich holozäne Verbreitung der europäischen Flusskrebe. Spixiana, 6 (1), 61-77.

ALDERMAN D.J., 1996. Geographical spread of bacterial and fungal diseases of crustaceans. Rev. sci. tech. Int. Epiz., 15 (2), 603-632.

ALEKHNOVICH A.V., ABLOV S.E., KULESH V.F., PAREIKO O.A., 1999a. Case studies of alien crayfish in Europe. The American spiny-cheek crayfish, Orconectes limosus (Rafinesque), in the fauna of Belarus. In : Crayfish in Europe as alien species. How to make the best of a bad situation? GHERARDI F., HOLDICH D.M. (Eds.), 237-242, A.A. Balkema, Rotterdam.

ALEKHNOVICH A., KULESH V., ABLOV S., 1999b. Growth and size structure of narrowclawed crayfish Astacus leptodactylus Esch. in its eastern area. Freshwater Crayfish, 12, 550-554.

ALEXANDROVA E., 1999. Pontastacus leptodactylus: cultivation and restoration of stocks in Central Russia. Freshwater Crayfish, 12, 563-572.

ALMAÇA C., 1990. Recursos animais e sua conservação as populações Portugesas do Lagostim-de-Rio, Astacus pallipes Lereboullet, 1858. Mus. Nac. Hist. Nat. 1990, Lisboa, Portugal, $22 \mathrm{p}$.

ALONSO F., TEMIÑO C., DIÉGUEZ-URIBEONDO J., 2000. Status of the white-clawed crayfish, Austropotamobius pallipes (Lereboullet, 1858), in Spain: distribution and legislation. Bull. Fr. Pêche Piscic., 356, 31-54.

ALONSO F., TEMIÑO C., DIÉGUEZ-URIBEONDO J., 2001. Actual conservation status of the white-clawed crayfish Austropotamobius pallipes (Lereboullet) in Spain. Knowledge-based management of European native crayfishes, Poitiers, France, September 13-15, 2001, Abstracts, p. 11. 
ARRIGNON J.C.V., 1996. Status of foreign crayfish in France. Freshwater Crayfish, 10, 665-670.

ARRIGNON J.C.V., GÉRARD P., KRIER A., LAURENT P.J., 1999a. Case studies of alien crayfish in Europe. The situation in Belgium, France and Luxembourg. In : Crayfish in Europe as alien species. How to make the best of a bad situation? GHERARDI F., HOLDICH D.M. (Eds.), 129-140, A.A. Balkema, Rotterdam.

ARRIGNON J.C.V., MARTIN M., MATTEI J., 1999b. Austropotamobius pallipes pallipes in Corsica (France). Freshwater Crayfish, 12, 811-816.

BALSS H., 1925. Spanische Süsswasser-Dekapoden. Senckenbergiana, 7, 206-209.

BARAN I., SOYLU E., 1989. Crayfish plague in Turkey. J. Fish Dis., 12, 193-197.

BARBARESI S., GHERARDI F., 2000. The invasion of the alien crayfish Procambarus clarkii in Europe, with particular reference to Italy. Biol. Invas., 2, 259-264.

BELL A., 1920. Notes on the Later Tertiary Invertebrata. Ann. Rep. Yorkshire Phil. Soc., 1920, 1-21.

BERNARDO J.M., ILHÉU M., COSTA A.M., 1997. Distribution, population structure and conservation of Austropotamobius pallipes in Portugal. Bull. Fr. Pêche Piscic., 347, 617-624.

BERNARDO J.M., BRUXELAS S., BOCHECHAS J., COSTA A.M., 2001a. Freshwater crayfish in Portugal: a new Astacidae, Pacifastacus leniusculus (Dana), and less perspectives for the rehabilitation of the native Austropotamobius pallipes. Actas II Congresso Nacioal de Conservação da Natureza, Lisboa, 2-5 Outubro 2001.

BERNARDO J.M., BRUXELAS S., MAIA M.J., TEIXEIRA A., SAMPAIO J., ILHÉU M., 2001b. Inevitable extinction of Austropotamobius pallipes in Portugal? Apparent failure of restocking actions. Knowledge-based management of European native crayfishes, Poitiers, France, September 13-15, 2001, Abstracts, p. 28.

BIRNSTEIN M.C., WINOGRADOW L., 1934. Die Süsswasserdekapoden der UdSSR und ihre geographische Verbreitung. Zool. J. Moscow, 13, 39-70.

BOHL E., 1997. An isolated population of the white-clawed crayfish (Austropotamobius pallipes) in the principality of Liechtenstein. Bull. Fr. Pêche Piscic., 347, 701-712.

BOHL E., 1999. Crayfish stock situation in Bavaria (Germany) - attributes, threats and chances. Freshwater Crayfish, 12, 765-777.

BOTT R., 1950. Die Flusskrebse Europas. Abh. senckenberg. naturf. Ges., 483, 1-36.

BOTT R., 1972. Besiedlungsgeschichte und Systematik der Astaciden West-Europeas unter besonderer Berücksichtigung der Schweiz. Rev. Suisse Zool., 79, 397-408.

BRINCK P., 1977. Developing crayfish populations. Freshwater Crayfish, 3, 211-228.

BRINK F.W.B. Van Den, VELDE D. Van Den, GEELEN J.F.M., 1988. Life history parameters and temperature-related activity of an American crayfish, Orconectes limosus (Rafinesque, 1817) (Crustacea, Decapoda), in the area of the major rivers in The Netherlands. Arch. Hydrobiol., 114, 275-289.

BRODSKY S.Ya., 1983. On the systematics of Palaearctic crayfishes (Crustacea, Astacidae). Freshwater Crayfish, 5, 464-470.

BUDHINA W., 1989. Further update on crayfish situation in Jugoslavia. Crayfish NEWS, $11(4), 4$.

BULGURKOV K., 1964. Astacus pachypus Rathke nov. Vid Rechen Rak za Bulgarskata Fauna. Ivestia na In- $t$ Ribolov, 5, 122-128.

BULLOCK J.M., HODDER K.H., MANCHESTER S.J., STEVENSON M.J., 1997. Review of information, policy and legislation on species translocation. JNCC Report 261. Joint Nature Conservation Committee, Peterborough. 128 p.

BURBA A., 1999. Remarkable changes in Lithuanian crayfish situation through the recent 35 years. Freshwater Crayfish, 12, 922.

CARRAL J.M., CELADA J.D., GONZÁLEZ J., SÁEZ-ROYUELA M., GAUDIOSO V.R., FERNÁNDEZ R., LÓPEZ-BAISSON C., 1993. Wild freshwater crayfish populations in Spain: current status and perspective. Freshwater Crayfish, 9, 158-162. 
CHANGEUX T., 1996. Premiers résultats de l'enquête express écrevisses. Conseil Supérieur de la Pêche, Circulaire D003 du 15/01/95, 5 p.

CHERKASHINA N.Ya., 1999a. Caspiastacus pachypus (Rathke, 1837), its biology and distribution. Freshwater Crayfish, 12, 846-853.

CHERKASHINA N.Ya., 1999b. The state of populations of Pontastacus cubanicus (Birnstein and Winogradow, 1934) in the waterbodies of the lower Don area (Russia). Freshwater Crayfish, 12, 643-654.

CORREIA A.M., COSTA A.C., 1994. Introduction of the red swamp crayfish, Procambarus clarkii (Crustacea, Decapoda) in São Miguel, Azores, Portugal. Arquipélago, 12A, 67-73.

CUELLAR L., CUELLAR M.C., 2000. Evolution de l'aphanomycose et repeuplements avec l'écrevisse signal (Pacifastacus leniusculus) en Espagne. L'Astaciculteur de France, 65, 2-9.

CUKERZIS J.M., 1988. Astacus astacus in Europe. In : Freshwater crayfish: biology, management and exploitation, HOLDICH D.M., LOWERY R.S. (Eds.), 309-340, Croom Helm, London.

D'AGARO E., DE LUISE G., LANARI D., 1999. The current status of crayfish farming in Italy. Freshwater Crayfish, 12, 506-517.

DEHUS P., BOHL E., OIDTMANN B., KELLER M., 1999a. Case studies of alien crayfish in Europe. German conservation strategies for native crayfish species with regard to alien species. In : Crayfish in Europe as alien species. How to make the best of a bad situation? GHERARDI F., HOLDICH D.M. (Eds.), 149-159, A.A. Balkema, Rotterdam.

DEHUS P., DUSSLING U., HOFFMANN C., 1999b. Notes on the occurrence of the calico crayfish (Orconectes immunis) in Germany. Freshwater Crayfish, 9, 786-790.

DELMASTRO G.B., 1992. II gambero Americano Orconectes limosus (Rafinesque), un nuovo decapode neartico nelle acque dolci del nord Italia. Ann. Mus. Civ. Sc. Nat., Brescia, 27 (1990-91), 171-174.

DELMASTRO G.B., 1999. Annotazione sulla storia naturale del gambero della Louisiana Procambarus clarkii (Girard, 1852) in Piemonte centrale e prima segnalazione regionale del gambero americano Orconectes limosus (Rafinesque, 1817) (Crustacea : Decapoda : Astacidae : Cambaridae). Riv. Piem. St. Nat., 20, 65-92.

DELMASTRO G.B., 2000. Un gambero a stele e strisce alla conquista dei nostri ambienti acquatica. Piemonte Parchi, 15 (6), 2-5.

DELMASTRO G.B., LAURENT P.J., 1997. Récentes avancées des écrevisses américaines en Italie. L'Astaciculteur de France, 50, 2-8.

DIÉGUEZ-URIBEONDO J., RUEDA A., CASTIEN E., BASCONES J.C., 1997. A plan for the restoration in Navarra for the freshwater crayfish species of Spain, Austropotamobius pallipes. Bull. Fr. Pêche Piscic., 347, 625-637.

DUBOIS J-P., GILLET C., LAURENT P.J., 1999. Alien crayfish in Lake Geneva. Freshwater Crayfish, 12, 801-810.

ĎURIŠ Z., 1989. Freshwater crayfish (Crustacea, Decapoda) distribution on the Ostravice River drainage area (Northern Moravia), and its preliminary ecological evaluation. Studia Oecologica, 2, 29-36.

DLURIŠ Z., 1999. On the distribution of the introduced crayfish Orconectes limosus in Poland. Freshwater Crayfish, 12, 830-834.

EDER E., HÖDL W. (Eds.), 1998. Flusskrebse Österreichs, Stapfia 58, Neue Folge 137, OÖ Landesmuseum, Lin, $284 \mathrm{p}$.

EDSMAN L., 2000. Crayfish conservation in Sweden, lesson to learn. In : Crayfish Conference Leeds, ROGERS D., BRICKLAND J. (Eds.), 19-25, Environment Agency, Leeds.

EDSMAN L., FARRIS J.S., KALLERSJÖ M., PRESTEGAARD T., 2002. Genetic differentiation between noble crayfish, Astacus astacus (L.), populations detected by microsatellite length variation in the rDNA ITS1 region. Bull. Fr. Pêche Piscic., 367, 691-706. 
FEDOTOV V.P., RAKHMANOV V.R., KUZNETSOV N.L., 1993. The crayfish stocks and the state of crayfish breeding in the north-west of Russia. Freshwater Crayfish, 9, 170-173.

FEDOTOV V.P., BYKADOROVA S.A., KHOLODKEVICH S.V., 1998. Crayfish situation in north-west of Russia. In : TAUGBØL T. (ed.), 65-74, Nordic-Baltic Workshop on Freshwater Crayfish Research and Management, May 23-26, 1998, ØF-Rapport nr. 26/1998, Eastern Norway Research Institute, Norway.

FRANCKHAUSER R., MACHINO Y., 2001. L'écrevisse de torrent (Austropotamobius torrentium) en France. L'Astaciculteur de France, 68, 2-5.

FROGLIA C., 1978. Guide per il riconoscimento delle specie animali delle acque interne italiane, vol. 4: Decapoda. Consignlio Nazionale delle Ricerche - Museo Civico di Storia Naturale di Verona, Verona. iv $+41 \mathrm{p}$.

FÜREDER L., MACHINO Y., 1995. Record of the white-clawed crayfish Austropotamobius pallipes (Lereboullet 1858) from Plansee (Tyrol, Austria). Ber. nat.-med. Verein Innsbruck, 82, 241-246.

FÜREDER L., MACHINO Y., 1998. Der Steinkrebs Austropotamobius torrentium (Schrank, 1803) im Haldensee (Tirol, Österreich) und weitere Nachweise van Flusskrebsen in hochgelegenen Gewässern. Ber. nat.-med. Verein Innsbruck, 85, 223-229.

FÜREDER L., MACHINO Y., 1999. Past and present crayfish situations in Tyrol (Austria and Northern Italy). Freshwater Crayfish, 12, 751-764.

FÜREDER L., OBERKOFLER B., HANEL R., MACHINO Y., 2001. Freshwater crayfish in South Tyrol (Italy): distribution and protection measures of endangered Austropotamobius pallipes. Bull. Fr. Pêche Piscic., 367, 651-662.

GABRIELIAN B., HOVHANNISIAN R., 1999. Introduction of Pontastacus leptodactylus (= Astacus leptodactylus) into Lake Sevan and its role in the reservoir's ecosystem. Freshwater Crayfish, 12, 930.

GARCÍA-ARBERAS L., RALLO A., 2000. Survival of natural populations of Austropotamobius pallipes in rivers in Bizkaia, Basque Country (north of Iberian Peninsula). Bull. Fr. Pêche Piscic., 356, 7-30

GEORGE W., 1962. Animal Geography. Heinemann, London. 142 p.

GERARD P., 1986. Les différentes espèces d'écrevisses en Belgique et leur répartition géographique. Travaux, Ser. D. No. 54, Station de Recherches Forestières et Hydrobiologiques, Belgique, $25 \mathrm{p}$.

GHERARDI F., HOLDICH D.M. (Eds.), 1999. Crayfish in Europe as alien species. How to make the best of a bad situation? A.A. Balkema, Rotterdam, 299 p.

GHERARDI F., BALDACCINI N., BARBARESI S., ERCOLINI P., DE LUISE G., MAZZONI D., MORI M., 1999. Case studies of alien crayfish in Europe. The situation in Italy. In : Crayfish in Europe as alien species. How to make the best of a bad situation? GHERARDI F., HOLDICH D.M. (Eds.), 107-128, A.A. Balkema, Rotterdam.

GOTTSTEIN S., KEROVEC M., MAGUIRE I., BUKVIĆ I., 1999. Ecological notes on Austropotamobius pallipes italicus (Faxon, 1914) (Decapoda, Astacidae) in a karstic spring of the Neretva Delta (Croatia). Freshwater Crayfish, 12, 620-628.

GRANDJEAN F., SOUTY-GROSSET C., 2000. Mitochondrial DNA variation and population genetic structure of the white-clawed crayfish, Austropotamobius pallipes pallipes. Conservation Genetics, 1, 309-319.

GRANDJEAN F., SOUTY-GROSSET C., HOLDICH D.M., 1997a. Mitochondrial DNA variation in four British populations of the white-clawed crayfish Austropotamobius pallipes pallipes, implications for management. Aquat. Living Resour., 10, 121-126.

GRANDJEAN F., SOUTY-GROSSET C., RAIMOND R., HOLDICH D.M., 1997b. Geographical variation of mitochondrial DNA between European populations of the white-clawed crayfish Austropotamobius pallipes. Freshwater Biology, 37, 493-501.

GRANDEAN F., HARRIS D.J., SOUTY-GROSSET C., CRANDALL K.A., 2000. Systematics of the European endangered crayfish species Austropotamobius pallipes (Decapoda: Astacidae). J. Crust. Biol., 20 (3), 524-531. 
GRANDJEAN F., GOUIN N., SOUTY-GROSSET C., DIEGUEZ-URIBEONDO J., 2001a. Drastic bottlenecks in the endangered crayfish species Austropotamobius pallipes in Spain and implications for its colonization history. Heredity, 86, 1-8.

GRANDJEAN F., FRELON-RAIMOND M., SOUTY-GROSSET C., 2001b. Phylogeography and post-glacial dispersion of the white-clawed crayfish, Austropotamobius pallipes species complex, in Western Europe. Knowledge-based management of European native crayfishes, Poitiers, France, September 13-15, 2001, Abstracts, p. 32.

GRANDJEAN F., FRELON-RAIMOND M., SOUTY-GROSSET C., 2002. Compilation of molecular data for the phylogeny of the genus Austropotamobius: one species or several? Bull. Fr. Pêche Piscic., 367, 671-680.

GROOMBRIDGE B. (ed.), 1993. 1994 IUCN Red List of Threatened Animals. IUCN Gland, Switzerland and Cambridge, UK, $286 \mathrm{p}$.

GUTIÉRREZ-YURRITA P.J., MARTINEZ J.M., 2001. Expected and potential ecological incidence of red swamp crayfish Procambarus clarkii in Tenerife Island, Canary Islands, Spain. Crayfish NEWS, 24 (1), 10-13.

GUTIÉRREZ-YURRITA P.J., MARTINEZ J.M., ILHÉU M., BRAVO-UTRERA M.A., BERNARDO J.M., MONTES C., 1999. Case studies of alien crayfish in Europe. The status of crayfish populations in Spain and Portugal. In : Crayfish in Europe as alien species. How to make the best of a bad situation? GHERARDI F., HOLDICH D.M. (Eds.), 161-192, A.A. Balkema, Rotterdam.

HENTONNEN P., HUNER J.V., 1999. The introduction of alien species in Europe: a historical introduction. In : Crayfish in Europe as alien species. How to make the best of a bad situation? GHERARDI F., HOLDICH D.M. (Eds.), 13-22, A.A. Balkema, Rotterdam.

HEWITT G.M., 1996. Some genetic consequences of ice ages, and their role in divergence and speciation. Biol. J. Linn. Soc., 58, 247-276.

HOLDICH D.M., 1992. Crayfish nomenclature and terminology: recommendations for uniformity. Finn. Fish. Res., 14, 149-155.

HOLDICH D.M., 1993. A review of astaciculture - freshwater crayfish farming. Aquat. Liv. Resour., 6 (3), 307-317.

HOLDICH D.M., 1996. Austropotamobius pallipes. In : Background information on invertebrates of the Habitats Directive and the Bern Convention, Part 1 - Crustacea, Coleoptera and Lepidoptera, VAN HELDDINGEN P.J., WILLEMSE I., SPEIGHT M.C.D. (Eds.), 1-8, Nature and environment 79, Strasbourg: Council of Europe Publishing.

HOLDICH D.M., 1999a. The negative effects of established crayfish introductions. In : Crayfish in Europe as alien species. How to make the best of a bad situation? GHERARDI F., HOLDICH D.M. (Eds.), 31-47, A.A. Balkema, Rotterdam.

HOLDICH D.M., 1999b. The introduction of alien crayfish into Britain for commercial exploitation - an own goal? In : The Biodiversity crisis and Crustacea, VON VAUPLE KLEIN J.C., SCHRAM F.R. (Eds.), 85-97, Proceedings of the $4^{\text {th }}$ International Crustacean Congress, Amsterdam, The Netherlands, July 20-24, 1998, Balkema, Rotterdam.

HOLDICH D.M., REEVE I.D., 1991. The distribution of freshwater crayfish in the British Isles with particular reference to crayfish plague, alien introductions and water quality. Aquatic Conservation, 1 (2), 139-158.

HOLDICH D.M., ROGERS W.D., 1997. The white-clawed crayfish, Austropotamobius pallipes, in Great Britain and Ireland with particular reference to its conservation in Great Britain. Bull. Fr. Pêche Piscic., 347, 597-616.

HOLDICH D.M., ROGERS W.D., READER J.P., 1995. Crayfish conservation. Final Project Record (378/10/N\&Y) for the National Rivers Authority, NRA, Bristol. 278 p.

HOLDICH D.M., GYDEMO R., ROGERS W.D., 1999a. A review of possible methods for controlling nuisance populations of alien crayfish. In : Crayfish in Europe as alien species. How to make the best of a bad situation? GHERARDI F., HOLDICH D.M. (Eds.), 245-270, A.A. Balkema, Rotterdam. 
HOLDICH D.M., ROGERS W.D., REYNOLDS J.D., 1999b. Case studies of alien crayfish in Europe. Native and alien crayfish in the British Isles. In : Crayfish in Europe as alien species. How to make the best of a bad situation? GHERARDI F., HOLDICH D.M. (Eds.), 221-235, A.A. Balkema, Rotterdam.

HOLDICH D.M., ACKEFORS H., GHERARDI F., ROGERS W.D., SKURDAL J., 1999c. Native and alien crayfish in Europe: Some conclusions. In : Crayfish in Europe as alien species. How to make the best of a bad situation? GHERARDI F., HOLDICH D.M. (Eds.), 281-292, A.A. Balkema, Rotterdam.

HOLDSWORTH E.W.H., 1880. Note on the distribution of the crayfish (Astacus) in Spain. Proc. Zool. Soc., Lond., 1880, 421-422.

HURT M., KIVISTIK M., PAAVER T., 1999. Changes in the state of noble crayfish stocks in lakes of southern Estonia in the period 1993-98. Freshwater Crayfish, 12, 540-549.

HUXLEY T.H., 1881. The crayfish. An introduction to the study of Zoology. Kegan Paul \& Co., London, $371 \mathrm{p}$.

JAŹDŹEWSKI K., KONOPACKA A., 1998. Immigration history and present distribution of alien crustaceans in Polish waters. Crustacean Issues, 12, 55-64.

KARAMAN M.S., 1962. Ein Beitrag zur Systematic der Astacidae (Decapoda). Crustaceana, 3, 173-191.

KARAMAN M.S., 1963. Studie der Astacidae (Crustacea, Decapoda) II. Teil. Hydrobiologia, 22, 111-132.

KISZELY P., 1999. Astacus astacus (L.) in the Balaton Region (Hungary) - a summary of surveys between 1992-1998 and future prospects. Freshwater Crayfish, 12, 817-824.

KÖKSAL G., 1988. Astacus leptodactylus in Europe. In : Freshwater crayfish: biology, management and exploitation, HOLDICH D.M., LOWERY R.S. (Eds.), 365-400, Croom Helm, London.

KOZÁK P., POLICAR T., ĎURIŠ Z., 2002. The stone crayfish Austropotamobius torrentium (Schrank) in the Czech Republic. Bull. Fr. Pêche Piscic., 367, 707-713.

KULESH V., ALEKHNOVICH A., ABLOV S., 1999. Distribution and size structure of noble crayfish, Astacus astacus (L.), populations in Belarus. Freshwater Crayfish, 12, 835-845.

LARGIADĖR C.R., HERGER F., LÖRTSCHER M., SCHOLL A., 2000. Assessment of natural and artificial propagation of the white-clawed crayfish (Austropotamobius pallipes species complex) in the Alpine region with nuclear and mitochondrial markers. Molecular Ecology, 9, 25-37.

LAURENT P.J., 1988. Austropotamobius pallipes and A. torrentium, with observations on their interactions with other species in Europe. In : Freshwater crayfish: biology, management and exploitation, HOLDICH D.M., LOWERY R.S. (Eds.), 341-364, Croom Helm, London.

LAURENT P.J., PARIS J.N., 1993. Five years of action in Lorraine and Morvan (France) to restore the noble crayfish, Astacus astacus. Freshwater Crayfish, 9, 380-389.

LAURENT P.J., SUSCILLON M., 1962. Les écrevisses en France. Ann. Stat. centre. hydrobiol. appl., 9, 333-397

LEWIS S.D., 2001. Crayfish of commercial importance. Pacifastacus. In : Biology of Freshwater Crayfish, HOLDICH D.M. (ed.), 511-540, Blackwell Science, Oxford.

LODGE D.M., TAYLOR C.A., HOLDICH D.M., SKURDAL J., 2000a. Nonindigenous crayfishes threaten North American freshwater biodiversity. Fisheries, 25 (8), 7-20.

LODGE D.M., TAYLOR C.A., HOLDICH D.M., SKURDAL J., 2000b. Reducing impacts of exotic crayfish introductions. Fisheries, 25 (8), 21-23.

LÖRTSCHER M., STUKI T.P., CLALÜNA M., SCHOLL A., 1997. Phylogeographic structure of Austropotamobius pallipes populations in Switzerland. Bull Fr. Pêche Piscic., 347, 649-661.

LOWERY R.S., HOLDICH D.M., 1988. Pacifastacus leniusculus in North America and Europe, with details of the distribution of introduced and native crayfish species in Europe. In : Freshwater crayfish: biology, management and exploitation, HOLDICH D.M., LOWERY R.S. (Eds.), 283-308, Croom Helm, London. 
MACHADO A., 1931. "Notas de Zoologia ». A existencia en Portugal de aqua doce Astacus fluviatilis. Ann. Soc. Sci. Porto, 16, 187-192.

MACHINO Y., 1996. L'écrevisse de torrent Austropotamobius torrentium (Schrank 1803) est au bord de l'extinction en Italie. L'Astaciculteur de France, 49, 9-12.

MACHINO Y., 1997a. Présence de l'écrevisse de Californie (Pacifastacus leniusculus) en Italie. L'Astaciculteur de France, 52, 2-5.

MACHINO Y., 1997b. New white-clawed crayfish Austropotamobius pallipes (Lereboullet, 1858) occurrences in Carinthia, Austria. Bull. Fr. Pêche Piscic., 347, 713-720.

MACHINO, Y., 1997c. Crayfish of the upper Soca and upper Sava rivers, Slovenia. Bull. Fr. Pêche Piscic., 347, 721-729.

MACHINO Y., 1999. Introductions clandestines de Pacifastacus leniusculus dans la région Rhône-Alpes. L'Astaciculteur de France, 60, 2-4.

MACHINO Y., 2000. Les écrevisses au Luxembourg. L'Astaciculteur de France, 62, 2-6.

MACHINO Y., 2001. Nouvelle observation astacologique au Luxembourg. L'Astaciculteur de France, 66, 2-3.

MACHINO Y., DIEGUEZ-URIBEONDO J., 1998. Un cas de peste des écrevisses en France dans le bassin de la Seine. L'Astaciculteur de France, 54, 2-11.

MAITLAND P.S., 1996. The North American signal crayfish, Pacifastacus leniusculus (Dana), established in the wild in Scotland. Aquatic Conservation, 6, 107-110.

MAITLAND P.S., CAMPBELL R.N., 1992. Freshwater fishes of the British Isles. New Naturalist Library. Harper Collins, London, 368 p.

MAITLAND P.S., SINCLAIR C., DOUGHTY C.R, 2001. The status of freshwater crayfish in Scotland in the year 2000. Glasgow Naturalist, 23 (6), 26-32.

MALYSHEV J.F., 1984. K povlavleniju shirokopalogi raka v basseine Verkhnej Obj. (On the appearance of Astacus astacus in the basin of the upper Ob). Izv. So., An SSSR, 6, 68-69 (in Russian).

MATEUS A., 1937. L'Astacus de Tras-os-Montes (Portugal). C. r. 12. Congr. Int. Zool., Lisbonne 1935, 3, 1564-1566.

MATINFAR A., 1999. Characteristics of Anzaly Lagoon crayfish Astacus leptodactylus. Freshwater Crayfish, 12, 937.

McNEELY J.A., MOONEY H.A., NEVILLE L.E., SCHEI P., WAAGE J.K. (Eds.), 2001. A global strategy on invasive alien species, IUCN Gland, Switzerland. and Cambridge, UK., in collaboration with the Global Invasive Species programme, $x+50 \mathrm{p}$.

MIKOUIZA A.S., SOKOLSKY A., USHIVTSEV V., KALMIKOV E., 1999. Biogeography of crayfish populations (Crustacea, Decapoda, Astacidae) in the Volga-Caspian region. Freshwater Crayfish, 12, 938.

NEVEU A., 1998a. Présence de l'aphanomycose en France : suivi d'un foyer dans l'ouest de 1990 à 1998. L'Astaciculteur de France, 57, 2-5.

NEVEU A., 1998b. Pacifastacus leniusculus : son rôle de vecteur et de réservoir de la peste des écrevisses (Aphanomycose). Etat actuel des connaissances. L'Astaciculteur de France, 57, 6-11.

NEVEU A., 2000. L'écrevisse de Louisiane (Procambarus clarkii) : réservoir permanent et vecteur saisonnier de l'Aphanomycose dans un petit étang de l'ouest de la France. L'Astaciculteur de France, 63, 7-11.

OBERKOFLER B., 2000. Vorkommen und Verbreitung von Flusskrebsen (Decapoda, Astacidae) in den Gewässern Südtirols. Diplomarbeit, Institut für Zoologie und Limnologie, Universität Innsbruck, Innsbruck, 118 p.

OBERKOFLER B., MACHINO Y., FÜREDER L., 2002. Occurrence of noble crayfish (Astacus astacus) in Italy. Ber. nat.-med. Verein Innsbruck, 89 , in press.

PAGOTTO G., PAGOTTO N., 1994. Prima segnalazione di Astacus astacus L. (Crustacea, Decapoda) autoctono in area italiana. In : Biologia dei salmonidi; tutela e gestione delle popolazioni indigene, Associazione Italiana Ittiologi Acque (ed.), 439-441, Atti del $5^{\circ}$ Convegno Nazionale, Villa Cordellina - Monteccio Maggiore (VI) 28-29 ottobre 1994, Assessorato alla Pesca, Amministrazione Provinciale de Vincenza, Vincenza.

PÖCKL M., 1999a. The distribution of native and introduced species of crayfish in Austria. Freshwater Forum, 12, 4-17. 
PÖCKL M., 1999b. Distribution of crayfish species in Austria with special reference to introduced species. Freshwater Crayfish, 12, 733-749.

POLICAR T., KOZÁK P., 2001. Freshwater crayfish in the Czech Republic. Knowledgebased management of European native crayfishes, Poitiers, France, September 1315, 2001, Abstracts, p. 35.

PUKY M., 2000. Distribution of some Decapoda species along the Hungarian Danube section and some tributaries with special emphasis on their conservation status. Internat. Assoc. Danube Res., 33, 285-290.

PUKY M., 2001. Conservation status of Decapoda species in Hungary. Knowledge-based management of European native crayfishes, Poitiers, France, September 13-15, 2001, Abstracts, p. 36.

RENZ M., BREITHAUPT T., 2000. Habitat use of the crayfish Austropotamobius torrentium in small brooks and in Lake Constance, southern Germany. Bull. Fr. Pêche Piscic., 356, $139-154$.

REYNOLDS J.D., 1997. The present status of freshwater crayfish in Ireland. Bull. Fr. Pêche Piscic., 347, 693-700.

REYNOLDS J.D., SOUTY-GROSSET C., GOUIN N., DEVANEY S., GRANDJEAN F., 2000. Experimental restocking of native crayfish in White Lake, Co. Westmeath (Ireland). In : Crayfish Conference Leeds. ROGERS D. and BRICKLAND J. (Eds.), 123-130. Environment Agency, Leeds.

REYNOLDS J.D., GOUIN N., PAIN S., GRANDJEAN F., DEMERS A., SOUTY-GROSSET C., 2002a. Irish crayfish populations: ecological survey and preliminary findings. Freshwater Crayfish, 13, 584-594.

REYNOLDS J.D., DEMERS A., MARNELL F., 2002b. Managing an abundant crayfish resource for conservation - A. pallipes in Ireland. Bull. Fr. Pêche Piscic., 367, 823-832.

RICHTER K., WILES R., 2000. Red swamp crayfish breeding in Britain. Crayfish NEWS, $23(1), 1,3$.

ROGERS W.D., HOLDICH D.M., 1995. Crayfish production in Britain. Freshwater Crayfish, 10, 583-595.

SALVIDIO S., CRESTA P., DORIA G., 1993. Preliminary survey on the distribution of the freshwater crayfish Austropotamobius pallipes in Liguria, N.W. Italy. Crustaceana, 65 (2), 218-221.

SALVIDIO S., MORI S., LATTE A., GALLI L., ARILLO A., 2002. The freshwater crayfish Austropotamobius pallipes (Lereboullet, 1858) in Liguria, NW Italy: implications for management at the regional level. Bull. Fr. Pêche Piscic., 367, 663-670.

SANTUCCI F., IACONELLI M., ANDREANI P., CIANCHI R., NASCETTI G., BULLINI L., 1997. Allozyme diversity of European freshwater crayfish of the genus Austropotamobius. Bull Fr. Pêche Piscic., 347, 663-676.

SCHULZ R., 2000. Status of the noble crayfish Astacus astacus (L.) in Germany: monitoring protocol and the use of RAPD markers to assess the genetic structure of populations. Bull. Fr. Pêche Piscic., 347, 123-138.

SIBLEY P.J., BRICKLAND J.H., BYWATER J.A., 2002. Monitoring the distribution of crayfish in England and Wales. Bull. Fr. Pêche Piscic., 367, 833-844.

SKURDAL J., TAUGBØL T., 2001. Crayfish of commercial importance. Astacus. In : Biology of Freshwater Crayfish, HOLDICH D.M. (ed.), 467-510, Blackwell Science, Oxford.

SKURDAL J., TAUGBØL T., BURBA A., EDSMAN L., SØDERBACK B., STYRRISHAVE B., TUUSTI J., WESTMAN K., 1999. Case studies of alien crayfish in Europe. Crayfish introductions in the Nordic and Baltic countries. In : Crayfish in Europe as alien species. How to make the best of a bad situation? GHERARDI F., HOLDICH D.M. (Eds.), 193-219, A.A. Balkema, Rotterdam.

SKURDAL J., GARNÅS E., TAUGBØL T., 2002. Management strategies, yield and population development of the noble crayfish Astacus astacus in Lake Steinsfjorden. Bull. Fr. Pêche Piscic., 367, 845-860. 
SOKOLSKY A.F., MIKOUIZA A.S., 2000. On taxonomy of the Volga-Caspian crayfish. Abstracts of the International Association of Astacology, $13^{\text {th }}$ Symposium, Perth, Australia, 6-12 August, 2000, p. 55.

SOKOLSKY A., USHIVTSEV V., MIKOUIZA A.S., KALMIKOV E., 1999. Influence of sea level fluctuations on wild crayfish populations in the Caspian Sea. Freshwater Crayfish, 12, 655-664.

SOKOLSKY A., MIKOUIZA A.S., KOLMIKOV E., OUSHIVTSEV V., KAMAKINE A., KOURACHOVA H., 2000. Biogéographie et particularités biologiques de l'écrevisse à pattes grêles (subfam. Astacinae, genus Pontastacus) dans la région d'Astrakhan. L'Astaciculteur de France, 63, 2-7.

SOUTY-GROSSET C., GRANDJEAN F., RAIMOND R., FRELON M., DEBENEST C., BRAMARD M., 1997. Conservation genetics of the white-clawed crayfish Austropotamobius pallipes: the usefulness of the mitochondrial DNA marker. Bull Fr. Pêche Piscic., 347, 677-692.

SOUTY-GROSSET C., GRANDJEAN F., GOUIN N., 1999, Molecular genetic contributions to conservation biology of the European native crayfish Austropotamobius pallipes. Freshwater Crayfish, 12, 371-386.

SOUTY-GROSSET C., REYNOLDS J., GOUIN N., GRANDJEAN F., 2000. Irish crayfish populations: ecology and genetics. Abstracts of the International Association of Astacology, $13^{\text {th }}$ Symposium, Perth, Australia, 6-12 August, 2000, p. 56.

SPINK J., FRAYLING M., 2000. An assessment of post-plague reintroduced native whiteclawed crayfish, Austropotamobius pallipes, in the Sherston Avon and Tetbury Avon, Wiltshire. Freshwater Forum, 14, 59-69.

STAROBOGATOV Ya.I., 1995. Taxonomy and geographical distribution of crayfishes of Asia and East Europe (Crustacea Decapoda Astacoidei). Arthropoda Selecta, 4 (3), 3-25.

STRUŻYŃSKI W.J., ŚMIETANA P., 1999. On the distribution of crayfish in Poland. Freshwater Crayfish, 12, 825-834.

STUBBS D., 1988. Towards an introductions policy. Conservation guidelines for the introduction and reintroduction of living organisms into the wild in Great Britain. London, Wildlife Link. 48 p.

STUCKI T.P., STAUB E., 1999. Case studies of alien crayfish in Europe. Distribution of crayfish species and legislation concerning crayfish in Switzerland. In : Crayfish in Europe as alien species. How to make the best of a bad situation? GHERARDI F., HOLDICH D.M. (Eds.), 141-147, A.A. Balkema, Rotterdam.

STUCKI T., JEAN-RICHARD P., 1999. Atlas de distribution des écrevisses de Suisse. Informations concernant la pêche, no. 65, 1-42, Office fédéral de l'environnement des forêts et du paysage (OFEFP), Berne.

SVÄRDSON G., 1995. The early history of signal crayfish introduction into Europe. Freshwater Crayfish, 8, 68-77.

TAUGBØL T., SKURDAL J., 1999. The future of native crayfish in Europe: How to make the best of a bad situation? In : Crayfish in Europe as alien species. How to make the best of a bad situation? GHERARDI F., HOLDICH D.M. (Eds.), 271-279, A.A. Balkema, Rotterdam.

TAYLOR C.A., 2001. Taxonomy and conservation of native crayfish stocks. In : Biology of Freshwater Crayfish, HOLDICH D.M. (ed.), 236-257, Blackwell Science, Oxford.

THÉOCHARIS V., 1986. La pêche à l'écrevisse dans la région d'Hipiros en Grèce. L'Astaciculteur de France, 8, 4-10.

TROSCHEL H.J., 1997. Distribution and ecology of Austropotamobius pallipes in Germany. Bull. Fr. Pêche Piscic., 347, 639-647.

TROSCHEL H.J., 1999. Distribution of crayfish species in Luxembourg. Freshwater Crayfish, 12, 791-795.

TROSCHEL H.J., DEHUS P., 1993. Distribution of crayfish species in the Federal Republic of Germany, with special reference to Austropotamobius pallipes. Freshwater Crayfish, 9, 390-398. 
TUUSTI J., PAAVER T., REIER A., 1993. Status of the noble crayfish (Astacus astacus) stocks in Estonia. Freshwater Crayfish, 9, 163-169.

UDEKEM D'ACOZ C. D'., 1999. Inventaire et distribution des crustacés décapodes de l'Atlantique nord-oriental, de la Méditerranée et des eaux continentales adjacentes au nord de $25^{\circ}$ N. Patrimoines naturels (M.N.H.N./S.P.N.), 40, $383 \mathrm{p}$.

VAN DER VELDE G., RAJAGOAL S., KELLEHER B., MUSKÓ I.B., BIJ DE VAATE A., 1998. Ecological impact of crustacean invaders: General considerations and examples from the River Rhine. Crustacean Issues, 12, 3-33.

VIELLE A., 1996. Situation de l'écrevisse en Valais (Suisse). L'Astaciculteur de France, 47, 2-6.

VIGNEUX E., 1997. Les introductions de crustacés décapodes d'eau douce en France. Peut on-parler de gestion ? Bull. Fr. Pêche Piscic., 344/345, 357-370.

VIGNEUX E., KEITH P., NOËL P., 1993. Atlas préliminaire des crustacés décapodes d'eau douce de France. Coll. Patrimoines Naturels, 14, S.F.F., B.I.M.M.-M.N.H.N., C.S.P., Min. Env., Paris, $55 \mathrm{p}$.

WEBB D.A., 1985. What are the criteria for presuming native species? Watsonia, 15, 231-236.

WESTMAN K., 1991. The crayfish fishery in Finland - its past, present and future. Fin. Fish. Res., 12, 187-216.

WESTMAN K., 1999. Review of historical and recent crayfish fishery, catch, trade and utilisation in Finland. Freshwater Crayfish, 12, 495-505.

WESTMAN K., PURSIAINEN M., WESTMAN P. (Eds.), 1990. Status of crayfish stocks, fisheries, diseases and culture in Europe. Report of the FAO European Inland Fisheries Advisory Commission (EIFAC) Working Party of Crayfish, 206 p. 